\title{
Türkiye'de Tabiat Parkları Koruma Amaçlı İmar Planlama Süreci: Ballıkayalar Tabiat Parkı Deneyimi
}

\author{
Z. Gamze MERT ${ }^{1 *}$, A. Kıvanç KUTLUCA ${ }^{2}$
}

Öz

Uluslararası literature göre "Doğal Alanlar" başlığı altında kabul edilen "Tabiat Parkları" uluslararası ve ulusal ölçekte mevzuatlar ve uluslararası, ulusal ve yerel ölçekte farklı kurumlar tarafından korunmaktadır. Türkiye'deki bu koruma anlayışının en önemli argümanı "Koruma Amaçlı İmar Planı" çalışmasıdır. Bu makalenin amacı, üniversitekamu kurumu işbirliği ${ }^{3}$ perspektifinde gerçekleşen, ülkemizin korunmaya değer önemli doğal alanlarından biri olan Ballıkayalar Tabiat Parkı için hazırlanan Ballıkayalar Koruma Amaçlı İmar Planı planlama süreci deneyimini aktarmaktır. Makaleye konu koruma amaçlı imar planlama çalışması üç aşamadan oluşmuştur. Birinci aşamada, literatür ve diğer ülke örnekleri incelenmiş, ikinci aşamada alanın analiz ve sentez çalışmaları yürütülmüş, üçüncü aşamada plan ve plan kararları oluşturulmuştur. Özellikle analiz aşamasında alan üzerine yapılan detaylı çalışmaların, uluslararası doğa parkları ile ilgili yapılan başarılı örneklerin ulusal boyutta projeye aktarılma gayretinin ve plan kararları kavramının hassas bir coğrafyada özel bir proje alanı vurgusu yapma istekliliğinin Ballıkayalar Tabiat Parkı deneyimi üzerinden, ulusal ölçekte tabiat parkı imar planlama çalışmalarına katkı sunması beklenmektedir.

Anahtar kelimeler: Tabiat Parkları, Koruma Amaçlı Imar Planı, Ballıkayalar, Türkiye

\section{Conservation Oriented Development Planning Process in Turkey: Ballıkayalar Natural Park Experience}

\section{ABSTRACT}

According to international literature "Natural Parks", accepted under the heading "Natural Habitats", are under the protection of different legislations and different institutions at international, national and local scale. The foremost argument for this protection concept in Turkey is the "Conservation Oriented Development Plan". This article aims to share planning process experience of "Ballıkayalar Conservation Oriented Development Plan" prepared for "Ballıkayalar Natural Park", one of the most important natural habitats in our country to be conserved, from a perspective of collaboration between the university and the public institution. The development of the subject of the Plan was composed of three phases. In the first phase, literature and other countries samples were examined, in the second phase analysis and synthesis studies were carried out while on the third stage the plan and the planning decisions were made. Particularly; the detailed studies on the field during the analysis phase, the

\footnotetext{
${ }^{1}$ Kocaeli Üniversitesi, Mimarlık ve Tasarım Fakültesi, Mimarlık Bölümü,

${ }^{2}$ Kocaeli Üniversitesi, Mimarlık ve Tasarım Fakültesi, Mimarlık Bölümü

* İlgili Yazar / Corresponding Author: gamzem@kocaeli.edu.tr

Gönderim Tarihi: 16.03 .2018

Kabul Tarihi: 28.03.2018

${ }^{3}$ Bu yayın, Orman ve Su İşleri Bakanlığı Kocaeli Şube Müdürlüğü'nün talebi doğrultusunda Kocaeli Üniversitesi Döner Sermaye İşletme Müdürlüğü aracılığı ile gerçekleşen "Ballıkayalar Tabiat Parkı Koruma Amaçlı Uygulama İmar Planı" çalışmasından üretilmiştir.
} 
efforts to implement the successful studies on international natural parks at the national level and finally on the planning decision concept, the eagerness to make a special project area on a delicate geography is expected to contribute to "conservation oriented development plan" on a national level through the experience acquired from the Ballıkayalar Natural Park experience.

Keywords: Natural Parks, Conservation Oriented Development Plan, Ballıkayalar, Turkey

\section{Giriş}

Doğal alanların çeşitli türleri bulunmaktadır. Sınıflandırılmaları ülkeden ülkeye farklıııklar gösterebilmekle birlikte Uluslararası Doğayı Koruma Birliği (IUCN) tarafından yapılan ve halen birçok ülkede uygulanmakta olan sınıflandırma, doğal alanları altı ana başlık altında toplamaktadır. Bunlar; "Mutlak Doğal Rezerv ve Yaban Hayat Alanları", "Milli Parklar", "Doğal Anıtlar", "Yönetilen Habitat/Türlerin Alanları", "Korunan Peyzaj Alanları" ve "Sürdürülebilir Kullanım Ile Korunan Doğal Kaynak Alanları"dır (URL-1). Bu sınıflandırmaya ve tanımlara göre tabiat parkları, ne doğal rezerv alanlarıdır ne de milli parklardır. Tabiat parklarının uluslararası kabul edilmiş bir tanımı bulunmamaktadır. Ancak ülkelerin ulusal ve yerel mevzuatları ve kurumları tarafından bu alanlar tanımlanmakta ve koruma-kullanma politikaları geliştirilmektedir.

Ülkemizde Tabiat Parkları, "Korunan Alanlar" başlığı altında tanımlanmaktadır. Orman ve Su İşleri Bakanlığı, Doğa Koruma ve Milli Parklar Genel Müdürlüğü'ne göre, korunan alanlar; "Ekosistem hizmetlerinin ve kültürel değerlerin, tabiatla birlikte uzun vadeli korunması ve devamılı̆̆ın sağlanması maksadıyla mevzuatla tanımlanan ve yönetilen coğrafi bir alandır." şeklinde tanımlanmaktadır. Korunan alanlar ise "Milli Parklar", "Tabiat Parkları", "Tabiat Anıtları", "Tabiati Koruma Alanlari" ve "Yaban Hayati Geliştirme Sahalari” şeklinde ayrılmaktadır. Günümüzde sayıları 223'e varan ülkemizdeki tabiat parklarından önemli biri de "Ballıkayalar Tabiat Parkı" dır.

Bu çalışmada, Ballıkayalar Tabiat Parkı deneyimi, Türkiye'de önemli bir kaynak değer oluşturan Tabiat Parklarını, koruma amaçlı imar planlama mevzuatını, tabiat parkları planlama sürecini açıklamakta ve bu sürecin uygulama deneyimini aktarmaktadır.

\section{DÜNYA'DA ve TÜRKIYE'DE TABIAT PARKLARI}

Ülkeden ülkeye tabiat parkları ve tanımları farklılık göstermektedir. Bu çalışma kapsamında, Dünya'daki Almanya, Avusturya, Fransa ve Kanada'nın yanında Türkiye'deki tabiat parklarına ve tanımlarına yer verilmektedir. Almanya'da Federal Doğa Koruma Kanununa göre (§ 27 of the Federal Nature Conservation Act (BNatSchG)) tabiat parkı; kullanım çeşitliliği sunan peyzaja ve geniş çeşitlilikte habitat ve türlere sahip, başlıca peyzaj koruma alanları ve doğal rezerv alanlardan oluşan, tek bir birim olarak geliştirilen ve yönetilen geniş alanlar olarak tanımlanmaktadır. Almanya'da 01.07.2012 tarihi itibariyle 104 adet tabiat parkı bulunmaktadır. Toplam 9 500000 ha alan büyüklüğüyle ülke topraklarının \%27 sini oluşturmaktadır (URL-2). Almanya'daki tabiat parklarını gösteren harita Şekil 1'de yer almaktadır. 


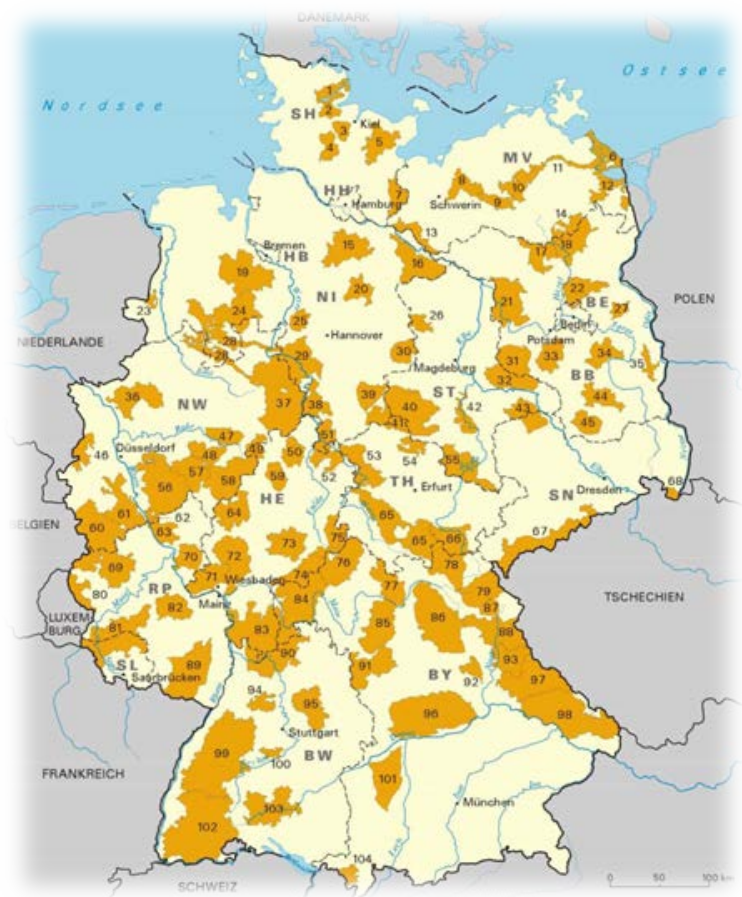

Şekil 1: Almanya'daki tabiat parklarını gösteren harita (URL-3)

Avusturya Doğal Parklar Kurumu'na (Association of Austrian Nature Parks(VNÖ)) göre tabiat parkları; yüzyıllar boyunca biçimlenerek bugünkü şeklini alan korunan peyzaj alanları olarak tanımlanmaktadır. Özel estetik değerlerine sahip bu kültürel peyzaj alanları çeşitli düzenlemelerle ziyaretçilere açılmakta ve rekreasyon alanı olarak erişilebilmektedir. Avusturya'da 500000 ha alan büyüklüğünde 48 adet tabiat parkı bulunmaktadır. Bu büyüklük ülke topraklarının \%6 sını kaplamaktadır (URL-4).

Avusturya'daki tabiat parklarını gösteren harita Şekil 2'de görülmektedir.

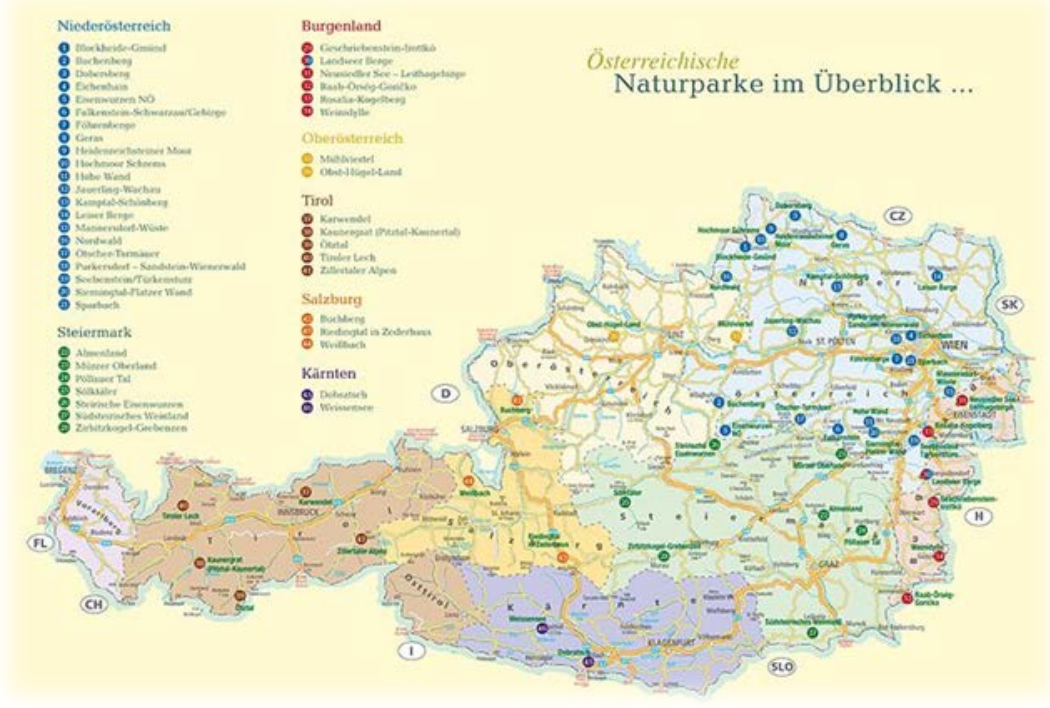

Şekil 2: Avusturya'daki tabiat parklarını gösteren harita (URL-5)

Fransa Bölgesel Tabiat Parkları Federasyonu (La Fédération des Parcs naturels régionaux de France) bölgesel tabiat park alanları ağının sözcüsüdür (URL-6). 
Federasyonuna göre tabiat parkları; yüksek kalitede doğal alanlar ve kültürel mirasa sahip kırılgan peyzaj alanları olarak tanımlanmaktadır (URL-7).

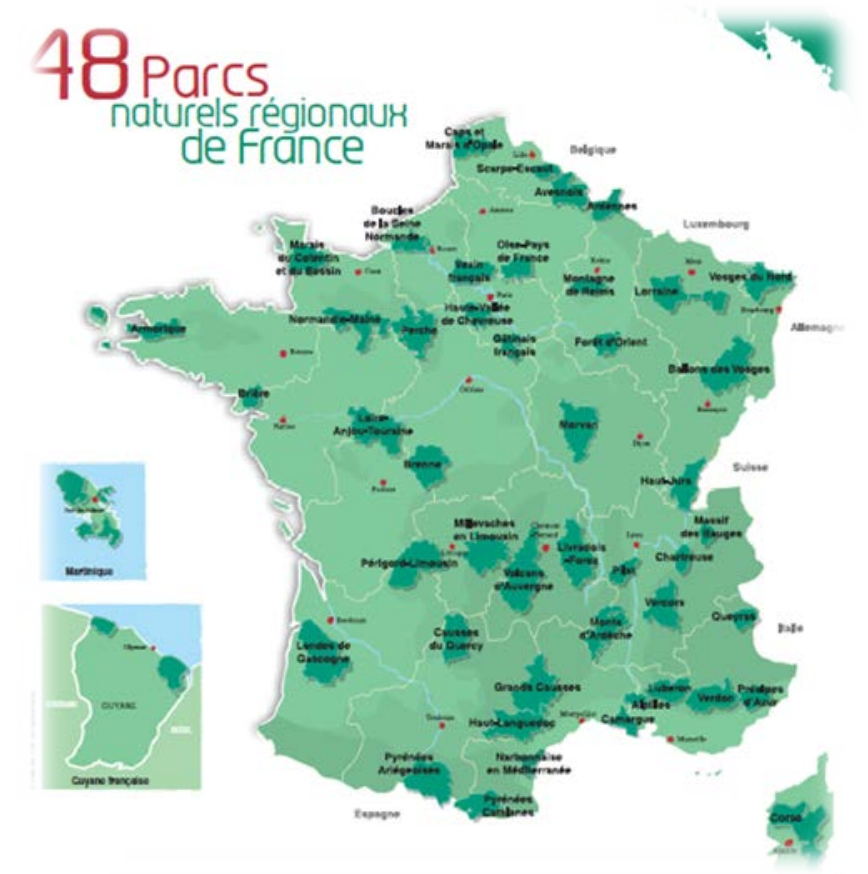

Şekil 3: Fransa'daki tabiat parklarını gösteren harita (URL-8)

Fransa'da toplam 7000000 ha alan büyüklügüne sahip 48 adet tabiat parkı bulunmaktadır. Bu da ülke topraklarının \%11 ine denk gelmektedir (Şekil 3).

Kanada'da tabiat parkları sadece bitkiler, hayvanlar için değil, insan ruhu için bir sığınak olarak görülmektedir. Doğal mirası temsil eden doğal ortamlar korunduğu gibi, doğaya, maceraya, keşfe açılan kapılar olarak da düşünülür. Bu kapsamda, Kanada'nın 39 doğal bölgesinin doğal manzara ve fenomenlerini koruma- kullanma dengesi içinde sunmak için Milli Parklar Sistem Planı kurulmuştur. Bu plan hem muhteşem doğal alanların ekosistemlerini korumak hem de ziyaretçilerin kendilerini tehlikeye atmayacak şekilde anlamaları, takdir etmeleri ve eğlenmelerini sağlamaktadır (URL-9). Ülkede bulunan toplamda 22270090 ha tabiat parkı alanı, Kanada 9985000 $\mathrm{km}^{2}$ yüzölçümünün $\% 0,23$ üne denk gelmektedir (Şekil 4). 


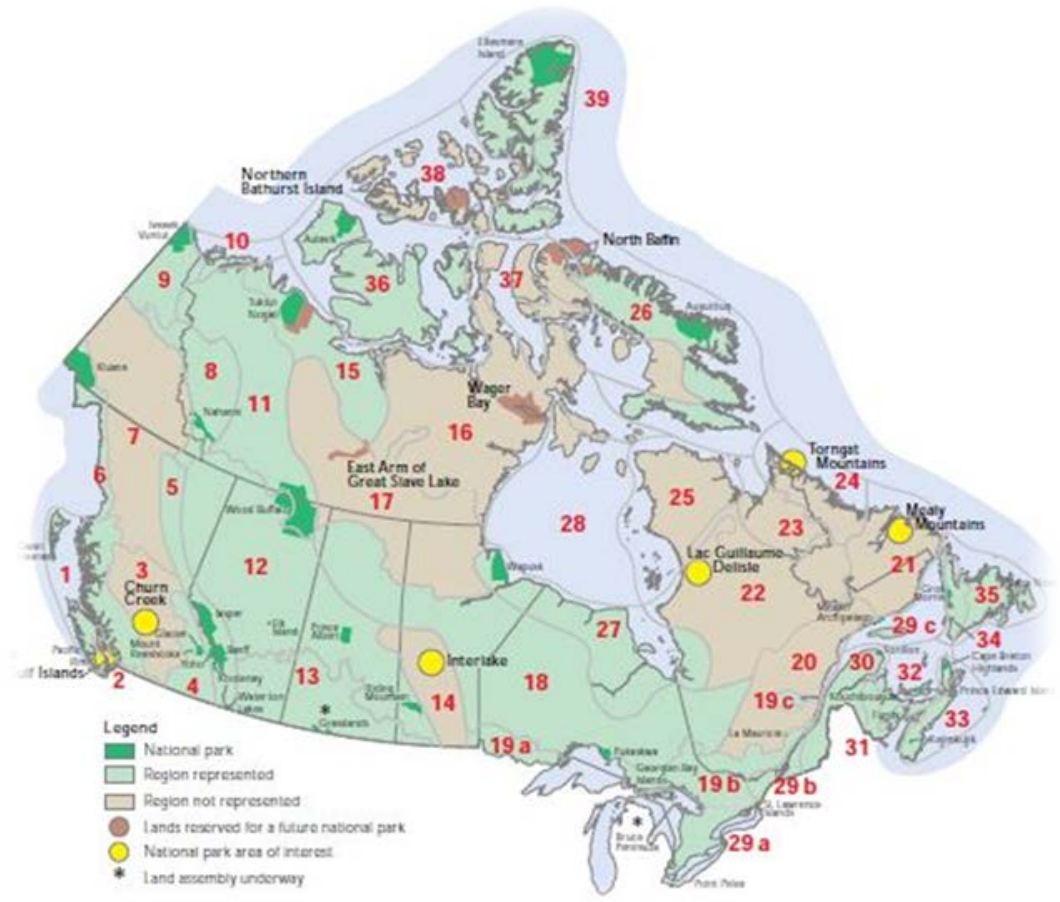

Şekil 4: Kanada'daki tabiat parklarını gösteren harita (URL-10)

Türkiye'de 2873 sayılı Milli Parklar Kanunu; milli parklar, tabiat parkları, tabiat koruma alanları ve tabiat anıtları olarak dört doğal alanı tanımlamakta ve bu alanların belirlenmesi, korunması, geliştirilmesi ve yönetilmesine ilişkin esasları düzenlemektedir. Bu kanuna göre tabiat parkları "bitki örtüsü ve yaban hayatı özelliğine sahip, manzara bütünlüğü içinde halkın dinlenme ve eğlenmesine uygun tabiat parçaları" olarak tanımlanmaktadır (Resmi Gazete, 1983a). Doğanay'a (2001) göre; bu tanımda geçen bitki örtüsü, doğal bitki örtüsünün tüm formasyonlarını; yaban hayatı, insan yaşamayan, yerleşilmemiş, doğal dengenin korunduğu alanlardaki flora fauna türlerinin doğal gelişme süreci içindeki durumlarını; manzara bütünlüğü, parkın görkemli genel görünüş ve çekici elemanlarını, tabiat parçası; ekosistem alanı, doğanın bir parçasını ifade etmektedir.

Ülkemizde ilan edilen ilk tabiat parkı, 1983 yılında belirlenip koruma altına alınmış olan, Muğla ilinin Fethiye ilçesi sınırları içindeki Ölüdeniz Kırdak Tabiat Parkıdır. Bu tarihten itibaren ülkemizde yıldan yıla tabiat parkları sayısında artış olmuştur. 2017 yılı itibariyle Türkiye'de toplam 101512 ha alan büyüklüğünde 223 adet tabiat parkı bulunmaktadır. Şekil 5 de Türkiye deki tabiat parklarının konumları görülmektedir. Bu büyüklük Türkiye'nin yüzölçümü 78,356,200 ha alanın \%0.13 üne denk gelmektedir. 


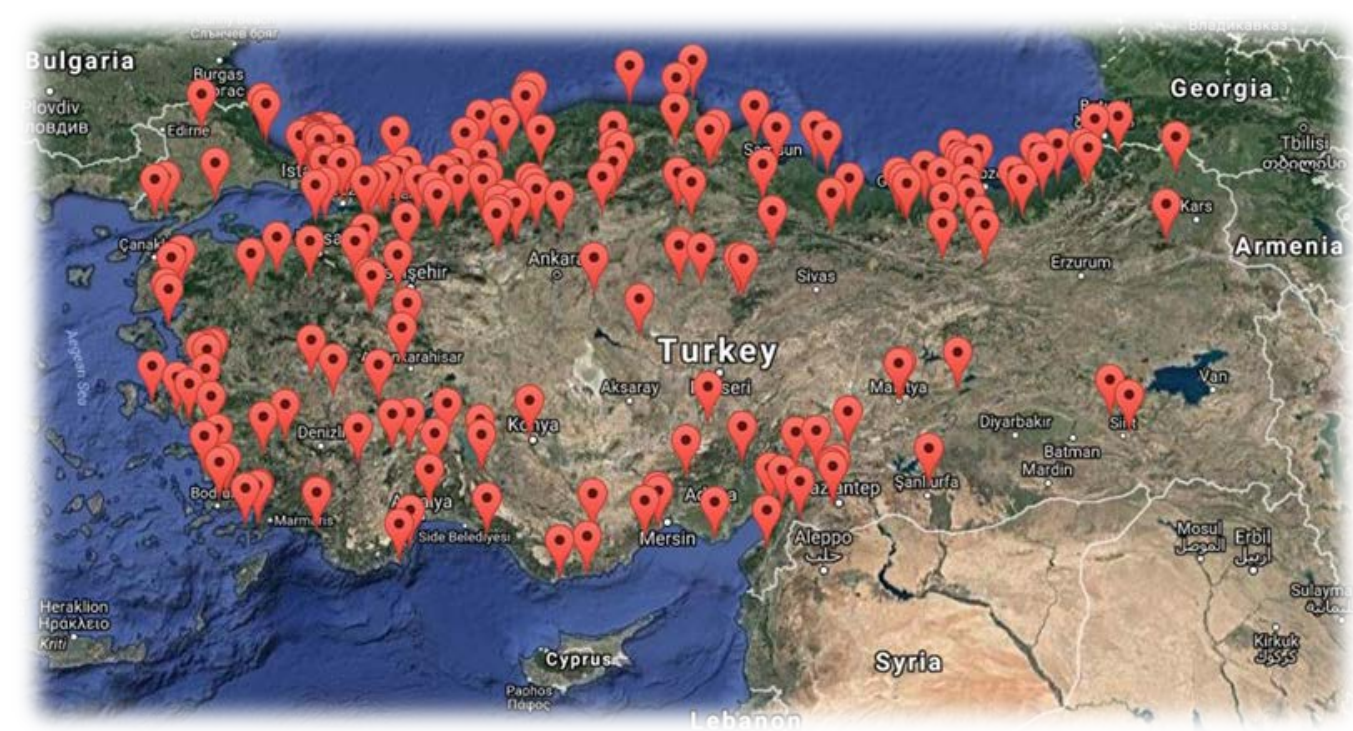

Şekil 5: Türkiye'de tabiat parklarının konumları (URL-11)

Yıllar itibariyle baktığımızda ilan edilmiş tabiat parklarının sayısındaki en önemli artışın 2011 yılında gerçekleştiği görülmektedir. 2010 yılında 40 adet tabiat parkı 2011 yılında 139 adet tabiat parkınında dahil olmasıyla ülkemizde tabiat parklarının sayısı 179 adet olmuştur (URL-12). 2017 yılı itibariyle de bu sayı 223'e ulaşmıştır. Yıllara göre tabiat parkı sayıları ve alan büyüklükleri Tablo 1 de verilmektedir.

Tablo 1: Türkiye'de yıllara göre tabiat parklarının sayıları ve alan büyüklükleri

\begin{tabular}{ccc} 
yıl & adet & alan büyüklüğü (ha) \\
\hline 1983 & 1 & 1020 \\
1984 & 2 & 1399 \\
1988 & 3 & 2644 \\
1989 & 5 & 4832 \\
1991 & 7 & 11279 \\
1994 & 9 & 26052 \\
1995 & 11 & 47279 \\
1998 & 15 & 54535 \\
2000 & 16 & 69227 \\
2002 & 17 & 69595 \\
2006 & 18 & 69622 \\
2007 & 20 & 70173 \\
2008 & 28 & 73436 \\
2009 & 37 & 74290 \\
2010 & 40 & 74529 \\
2011 & 179 & 81332 \\
2012 & 184 & 82278 \\
2013 & 189 & 89832 \\
2014 & 201 & 96963 \\
2015 & 204 & 99394 \\
2016 & 209 & 99378 \\
2017 & 223 & 101512 \\
\hline
\end{tabular}

Türkiye'de tabiat parkları, T.C. Orman ve Su İşleri Bakanlığına bağı Doğa Koruma ve Milli Parklar Genel Müdürlüğünün sorumluluğu altında Milli Parklar Dairesi Başkanlığının görev ve kapsamına girmektedir. 


\section{TÜRKIYE'DE TABIATT PARKLARI ILGILI MEVZUAT VE PLANLAMA SÜRECI}

\subsection{Illgili mevzuat, plan türleri ve tanımları}

Türkiye'de Tabiat Parkları ve korunan diğer doğal alanlarla ilgili hükümler, çeşitli kanun, yönetmelik, genelge, yönerge ve ilke kararlarında yer almaktadır. Bunlar; milli park, tabiat parkı, tabiat anıtı ve tabiatı koruma alanlarının belirlenmesi, korunması, geliştirilmesi ve yönetilmesine ilişkin esasları düzenleyen 9 Ağustos 1983 tarih 2873 sayılı Milli Parklar Kanunu (Resmi Gazete, 1983a), Milli Parklar Kanunu ile 6831 sayılı Orman Kanunu'nun 25. maddesinin uygulanmasını düzenleyen 12 Aralık 1986 tarih 19309 sayı ile yayınlanan Milli Parklar Yönetmeliği (Resmi Gazete, 1986), 18 Mart 2014 tarih 28945 sayı ile yürürlüğe giren Milli Parklar Yönetmeliğinde Değişiklik Yapılmasına Dair Yönetmelik (Resmi Gazete, 2014a), korunması gerekli taşınır ve taşınmaz kültür ve tabiat varlıkları ile ilgili tanımları belirleyen, yapılacak işlem ve faaliyetleri düzenleyen 21 Temmuz 1983 tarih 2863 sayılı Kültür ve Tabiat Varlıklarını Koruma Kanunu (Resmi Gazete, 1983b), 26 Temmuz 2005 tarih 25887 sayılı Koruma Amaçlı İmar Planları ve Çevre Düzenleme Projelerinin Hazırlanması, Gösterimi, Uygulaması, Denetimi ve Müelliflerine İlişkin Usul ve Esaslara Ait Yönetmelik (Resmi Gazete, 2005), bu yönetmelikte yer alan doğal sit alanlarına ilişkin hükümleri yürürlükten kaldıran 5 Ocak 2017 tarih 29939 sayılı Koruma Amaçıı İmar Planları ve Çevre Düzenleme Projelerinin Hazırlanması, Gösterimi, Uygulaması, Denetimi, Müelliflerine İlişkin Usul ve Esaslara Ait Yönetmelikte Değişiklik Yapılmasına Dair Yönetmelik (Resmi Gazete, 2017a), "milli parklar, tabiat parkları, tabiat anıtları, tabiatı koruma alanları, sulak alanlar, özel çevre koruma bölgeleri ve benzeri koruma statüsü bulunan diğer alanlarda yapılacak planlar ile doğal sit alanlarında yapılacak koruma amaçlı imar planlarının hazırlanması, yapım esasları, gösterimi, onaylanması, uygulaması, denetimi ve bu planları hazırlayacak müelliflerin nitelikleri ile görev, yetki ve sorumluluklarına ilişkin usul ve esasları belirleyen" 23 Mart 2012 tarih 28242 sayılı Korunan Alanlarda Yapılacak Planlara Dair Yönetmelik (Resmi Gazete, 2012), Çevre ve Şehircilik Bakanlığı'nın 16 Temmuz 2012 tarih ve 5035 sayılı olurlarıyla yürürlüğe giren "Korunan Alanlarda Plan İnceleme ve Sonuçlandırılmasına İlişkin Yönerge" ve eki "Korunan Alanlarda Yapılacak İmar Planı Teklifi Usul ve Esasları", bu yönerge ve ekleri yürürlükten kaldırarak koruma statüsü bulunan alanlarda yapılacak planlarla, doğal sit alanlarında yapılacak koruma amaçlı imar planlarının incelenmesi ve onaylanmasına ilişkin husuları içeren 27 Ekim 2014 tarih ve 10742 sayı ile yürürlülüğe giren Korunan Alanlarda Yapılacak İmar Planı Teklifi Usul ve Esaslarına İlişkin 2014/23 nolu Genelge (Çevre ve Şehircilik Bakanlığı, 2014), "fiziki, doğal, tarihi ve kültürel değerleri korumak ve geliştirmek, koruma ve kullanma dengesini sağlamak, ülke, bölge ve şehir düzeyinde sürdürülebilir kalkınmayı desteklemek, yaşam kalitesi yüksek, sağlıklı ve güvenli çevreler oluşturmak üzere hazırlanan, arazi kullanım ve yapılaşma kararları getiren mekânsal planların yapımına ve uygulanmasına ilişkin usul ve esasları belirleyen" 14 Haziran 2014 tarih ve 29030 sayılı Mekansal Planlar Yapım Yönetmeliği (Resmi Gazete, 2014b), doğal sit alanlarının güncel durumu ile Korunan Alanların Tespit, Tescil ve Onayına İlişkin Usul ve Esaslara Dair Yönetmelik doğrultusunda 25 Ocak 2017 tarih 29959 sayı ile resmi gazetede yayınlanan 5 Ocak 2017 tarih 99 sayılı Doğal Sit Alanları Koruma ve Kullanma Koşulları İlke Kararı(Resmi Gazete, 2017b) ndan oluşmaktadır.

Mevzuat çerçevesinde Türkiye'de doğal sit alanı statüsüne de sahip olan tabiat parklarında ve korunan diğer doğal alanlarda yapılacak planlara yer verilmektedir. Bu 
kapsamda; Korunan Alanlarda Yapılacak Plan, Uzun Devreli Gelişme Planı(UDGP) ve Koruma Amaçlı İmar Planı tanımlanmaktadır.

Korunan Alanlarda Yapılacak Plan, "Milli parklar, tabiat parkları, tabiat anıtları, tabiatı koruma alanları, sulak alanlar, özel çevre koruma bölgeleri ve benzeri koruma statüsü bulunan diğer alanlarda, .... hedefler, araçlar, stratejiler ile planlama kararları, tutumları, plan notları ve açıklama raporu ile bir bütün olan her tür ve ölçekte planlar," olarak tanımlanarak mevzuatta tabiat parkları ve korunan diğer doğal alanların planları için genel bir çerçeve çizilmektedir (Resmi Gazete, 2012).

Hem imar mevzuatında hem de korunan alanların mevzuatında adı geçen Uzun Devreli Gelişme Planı ise tabiat parkları ve korunan diğer alanlar için bölgelemeye dayalı ekosistem yaklaşımlı plan olarak tanımlanmakta ve Mekansal Planlar Yapım Yönetmeliği'nde "...teknik, sosyal, ekonomik, eylem ve yönetim modellerinin belirlendiği, ilişkilerin kurulduğu..." bir plan olarak belirtilmektedir. Ayrıca bu planın mekansal plan kademelenmesinde yer almadığı belirtilerek, "planlara girdi sağlayan ve imar planı kararlarına veri oluşturan veya gerektiğinde mekânsal planların uygulanmasına yönelik araç ve ayrıntıları da içerebilen, stratejik plan yaklaşımı ile gerektiğinde şematik ve grafik planlama dili kullanılarak yapılan, plan paftası, eylem planı ve planlama raporu ile bütün olan çalışmalardır. "Ifadesine yer verilmektedir (Resmi Gazete, 2014b).

Mevzuatta belirtildiği üzere Tabiat parkları ve korunan diğer doğal alanlarda öncelikle Uzun Devreli Gelişme Planı(UDGP) hazırlanmaktadır. Bu planın amacı; kaynak değerlerini korumak ve devamlılığını sağlamak, koruma-kullanma dengesi gözetilerek arazi kullanım kararlarını geliştirmek, sosyo-ekonomik faaliyetleri belirlemektir. İki kısımdan oluşur. Öncelikle yapılan analitik etüt çalışmaları ile geniş bir veri tabanı oluşturmakta, sentez ve değerlendirme ile birlikte uygulama için ilke, karar, proje ve programları tanımlamakta, yönetim organizasyonu önermektedir. Gelişme planları Çevre ve Şehircilik Bakanlığı'nın da görüşü alınarak Orman ve Su İşleri Bakanlığınca yapılmakta/yaptırılmakta ve yürürlüğe konmaktadır. 2016 yılı itibariyle Türkiye'de ilan edilen 209 adet tabiat parkından 101 adedinin gelişme planı bulunmaktadır (URL-12).

Uzun Devreli Gelişme Planı'nda yapılaşma öngörülen alanlar için planda belirtilen ilke ve hedefler doğrultusunda $1 / 5000$ ölçekli nazım ve 1/1000 ölçekli uygulama imar planları hazırlanmaktadır. Tabiat parkı ve korunan diğer doğal alanlar aynı zamanda doğal sit alanı statüsünde olması halinde, yine UDGP'na uygun olarak yapılaşma koşulları Koruma Amaçlı İmar Planları aracılığıyla belirlenmektedir. Korunan Alanlarda Yapılacak Planlara Dair Yönetmelik'te Koruma Amaçlı İmar Planı; "2863 sayılı Kültür ve Tabiat Varlıklarını Koruma Kanunu uyarınca belirlenen doğal sit alanları ve kentsel, arkeolojik, tarihi sit alanları ile çakışan doğal sit alanlarının büyüklüğü ve özelliğine göre, doğal ve çevresel değerlerin etkileşim-geçiş sahası da dikkate alınarak sürdürülebilirliğini, mutlak korunmasını ve gelecek nesillere intikalini sağlamak amacıyla halihazır haritalar ve mülkiyet verilerine dayalı olarak, gerekli asgari meslek gruplarının ortak çalışması ile istihdam ve katma değer yaratan stratejileri, koruma esaslarını, sağlıklaştırma, yenilenme projelerini, uygulama etap ve programlarını, açık alan sistemini, yaya dolaşımı ve varsa taşıt ulaşımını, altyapı tesislerinin tasarım esaslarını, yerel sahiplilik, uygulamanın finansmanı ilkeleri uyarınca katılımcı alan yönetimi modellerini de içerecek şekilde hazırlanacak, hazırlatılacak hedefler, araçlar, stratejiler ile planlama kararları, tutumları, plan notları ve açıklama raporu ile bir bütün olan nazım ve uygulama imar planları", olarak tanımlanmaktadır (Resmi Gazete, 2012). 
Bu çerçeve tanımla birlikte 3194 sayılı İmar Kanunu (Resmi Gazete, 1985) ile Mekansal Planlar Yapım Yönetmeliği (Resmi Gazete, 2014b) nde adı geçen nazım imar planı genelde $1 / 5000$ ölçekte, bölgenin genel kullanış biçimlerini, nüfus yoğunluklarını, yapı yoğunluğunu, ulaşım sistemlerini gösteren, uygulama imar planlarının hazırlanmasına esas olmak üzere düzenlenirken; 1/1000 ölçekte hazırlanan uygulama imar planı, bölgelerin yapı adalarını, bunların yapılaşma koşullarını ve yolları ayrıntılı olarak gösterir.

Belirtildiği üzere, 1/5000 nazım ve 1/1000 uygulama imar planlarının yapılaşma koşulları, Uzun Devreli Gelişme Planı (UDGP) nda belirlenen ilke ve kararlara göre uygulanmaktadır. Dolayısıyla Türkiye'de mevzuat içinde yer almakla beraber, mekansal plan kademelenmesinde yer almayan UDGP, tabiat parkları için üst ölçekli bağlayıcı fiziksel bir plan ve rapor niteliğindedir.

\subsection{Imar planları yapım süreci}

Korunan Alanlarda Yapılacak Planlara Dair Yönetmeliği (Resmi Gazete, 2012) ne göre, 1/5000 ölçekli koruma amaçlı nazım imar planı ve 1/1000 ölçekli koruma amaçlı uygulama imar planları eş zamanlı olarak hazırlanmalıdır. Aynı Yönetmeliğin 5. ve 6. maddeleri doğal sit alanlarında yapılacak koruma amaçlı imar planlarına ilişkin ilkeleri ile milli park, tabiat parkları, sulak alanlar ve benzeri korunan alanlarda yapılacak her tür ve ölçekteki planlara ilişkin ilkeleri belirtirken, Mekansal Planlar Yapım Yönetmeliği (Resmi Gazete, 2014b) nin 8. Bölüm 27. maddesi koruma amaçlı imar planı hazırlama ilkelerine yer vermektedir. 26.07.2005 tarih ve 25887 sayılı Koruma Amaçlı İmar Planları ve Çevre Düzenleme Projelerinin Hazırlanması, Gösterimi, Uygulaması, Denetimi ve Müelliflerine İlişkin Usul ve Esaslara Ait Yönetmelikte (Resmi Gazete, 2005) belirtilen hususlar çerçevesinde doğal sit alanlarında imar planlama çalışmaları yapılırken, 05.01.2017 tarih ve 29939 sayılı Koruma Amaçlı İmar Planları ve Çevre Düzenleme Projelerinin Hazırlanması, Gösterimi, Uygulaması, Denetimi, Müelliflerine İlişkin Usul ve Esaslara Ait Yönetmelikte Değişiklik Yapılmasına Dair Yönetmelik (Resmi Gazete, 2017a) ile doğal sit alanlarında yapılacak plan ve proje çalışmaları söz konusu yönetmeliğin kapsamı dışına alınmış ve aynı tarihte 99 sayılı lilke Kararı (Resmi Gazete, 2017b) ile doğal sit alanlarını koruma ve kullanma koşulları belirlenmiştir. Tabiat Parkında imar planlama çalışmaları burada bahsedilen sözkonusu yönetmelik ve ilke kararlarında yer alan hükümler ile Uzun Devreli Gelişme Planı (UDGP) nda belirlenen ilke ve kararlara göre yapılmaktadır.

Planlaması yapılan tabiat parkları, koruma statüsü bulunan diğer alanlar ile çakıştığı durumlarda ilgili bakanlıkların koruma ve kullanma esaslarına ilişkin görüşü alınmaktadır. Böylece birden fazla kurumun ve mevzuatın dahil olduğu bir süreç yaşanmaktadır.

\subsection{Imar planları inceleme ve onaylama süreci}

Türkiye'de tabiat parkları ve diğer korunan alanların plan inceleme ve onaylama sürecinde; Çevre ve Şehircilik Bakanlığı, İ Müdürlükleri ile Tabiat Varlıklarını Koruma Genel Müdürlügü, Tabiat Varlıkları Koruma Bölge Komisyonları yer almaktadır. "Korunan Alanlarda Yapılacak Planlara Dair Yönetmelik" in 7. Maddesi planların onaylanmasına dair hükümleri içermektedir. Ayrıca milli parklar, tabiat parkları, tabiat anıtları, tabiatı koruma alanları, sulak alanlar, özel çevre koruma bölgeleri ve benzeri koruma statüsü bulunan diğer alanlarda yapılacak planlar ile doğal sit alanlarında yapılacak koruma amaçlı imar planlarının incelenmesi ve onaylanmasına ilişkin 
hususları tanımlamak üzere; Çevre ve Şehircilik Bakanlığı'nın 16.07.2012 tarih ve 5035 sayılı olurlaryla yürürlüğe giren "Korunan Alanlarda Plan İnceleme ve Sonuçlandırılmasına İlişkin Yönerge" ve eki "Korunan Alanlarda Yapılacak İmar Planı Teklifi Usul ve Esasları" yürürlükten kaldırılarak, 27.10.2014 tarih ve 10742 sayı ile giren "Korunan Alanlarda Yapılacak İmar Planı Teklifi Usul ve Esaslarına İlişkin 2014/23 nolu Genelge" yürürlüğe girmiştir.

Türkiye'de tabiat parkları ve diğer korunan alanlara ilişkin her tür ve ölçekteki planlar öncelikle Çevre ve Şehircilik İI Müdürlüğü'ne sunulmakta, ilgili mevzuat çerçevesinde yapılan incelemeler sonrasında teknik rapor ile Tabiat Varlıklarını Koruma Genel Müdürlüğüne gönderilmektedir. Tabiat Parkı ve diğer korunan alanlar aynı zamanda sit alanı ise; ilgili bakanlıkların görüşü alındıktan sonra, Tabiat Varlıklarını Koruma Bölge Komisyonu kararı ile birlikte Tabiat Varlıklarını Koruma Genel Müdürlüğüne sunulmakta ve Genel Müdürlükte planlar Plan İnceleme Kurulu tarafından değerlendirilmekte, varsa gerekli düzeltmeler yapılarak Çevre ve Şehircilik Bakanlığı tarafından onaylanmaktadır.

\section{BALLIKAYALAR TABIAT PARKI KORUMA AMAÇLI IMAR PLANI ÇALIŞMASI}

\subsection{Balıkayalar Tabiat Parkı'na ilişkin genel bilgiler}

Ballıkayalar Tabiat Parkı Marmara Bölgesi, Kocaeli ili, Gebze ilçesi ve Dilovası ilçesi, Kocaeli Büyükşehir Belediyesi yetki sınırları içerisinde bulunmaktadır. Tabiat Parkı içerisinden geçen ve kuzeyden güneye doğru ilerlerken sırasıyla Ayvalık Deresi, Deli Dere, Gürgen Deresi ve Ballıkayalar Deresi isimlerini alan dere tabiat parkını iki farklı belediyenin sınırları içerisinde bırakmıştır. Derenin doğusunda kalan kısım Dilovası Belediyesi sınırları içerisinde yer alırken batıda kalan kısım Gebze Belediyesi sınırları içerisindedir. D100 karayolu ile E 80 TEM otoyolu alanının yaklaşık $4 \mathrm{~km}$. güneyinden geçmektedir (Şekil 6).

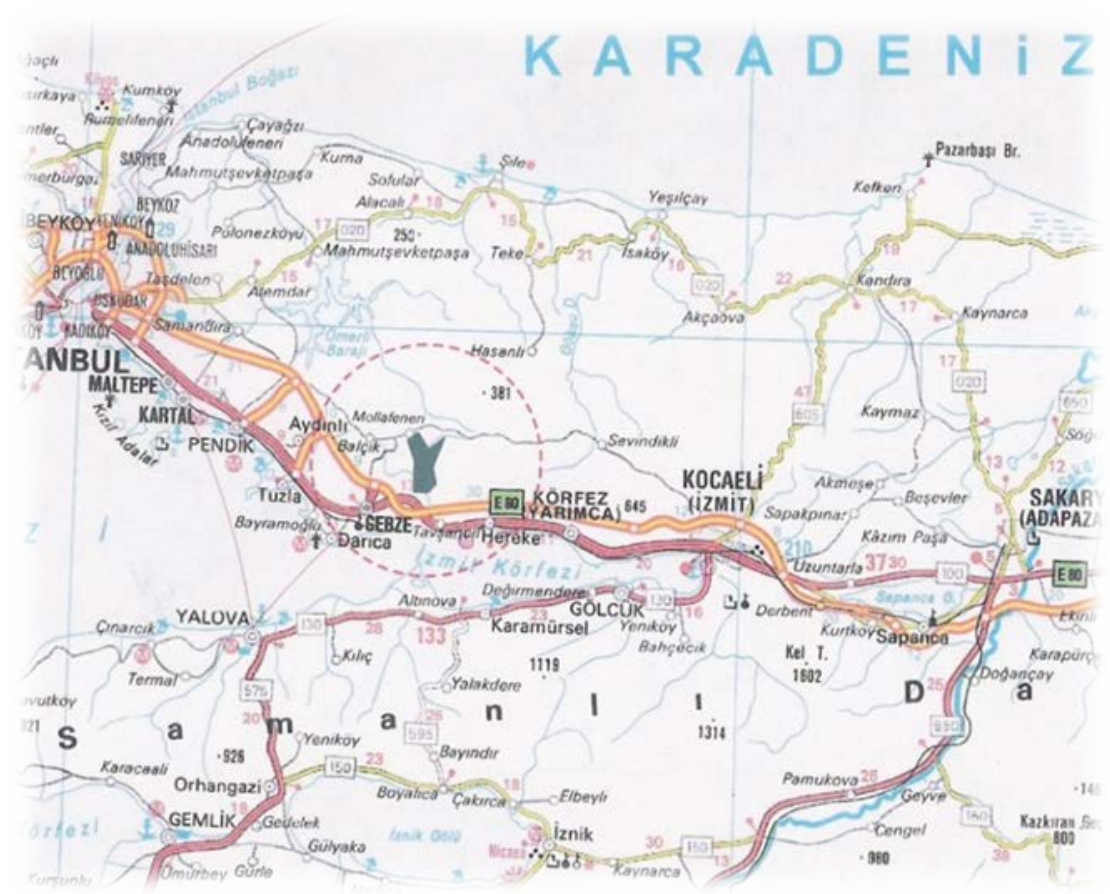

Şekil 6: Ballıkayalar Tabiat Parkı konumunu gösteren harita

(T.C. Çevre ve Orman Bakanlığı Doğa Koruma ve Milli Parklar Genel Müdürlüğü, 2004) 


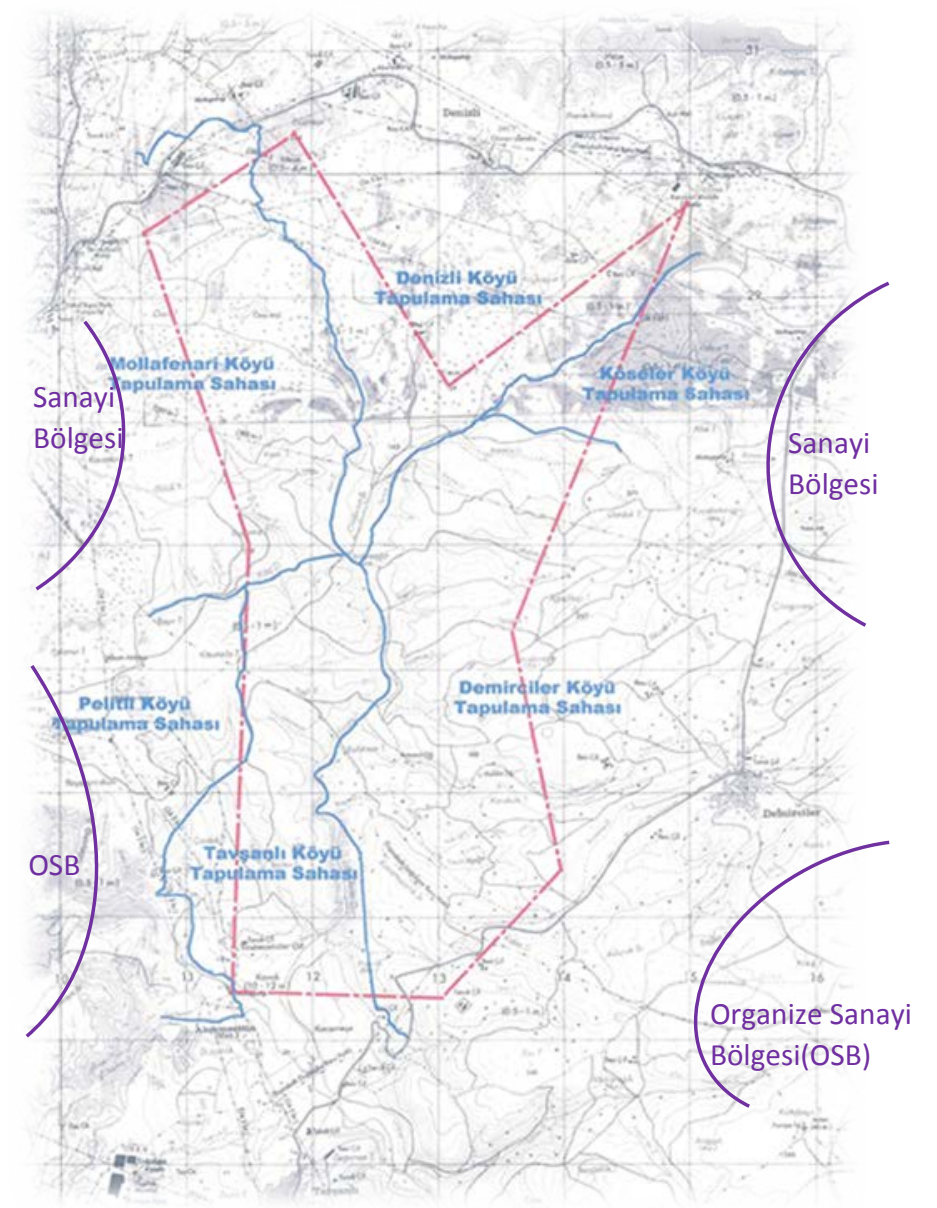

Şekil 7: Ballıkayalar Tabiat Parkı çevresi sanayi ve yerleşim bölgeleri

Tabiat Parkı çevresinde Organize Sanayi Bölgeleri yanında çeşitli büyüklükte sanayi tesisleri, depolama alanları ile Tavşanlı, Demirciler, Köseler, Denizli ve Pelitli köyleri ile Mollafenari (Akören) bucağı yerleşim bölgeleri yer almakta (Şekil 7) ve Tabiat parkı içerisinde bu yerleşimlere ait özel mülkiyetli alanlar bulunmaktadır.

Park, jeolojik, jeomorfolojik, flora, fauna, ekolojik, peyzaj ve rekreasyonel kaynak değerleri açısından zengin bir alandır (Fot.1). Ballıkayalar vadisi derin kanyon tipi özelliği göstermekte, alanda küçük çağlayanlar yanında göllenmeler ve çeşitli su kaynakları da görülmektedir. Vadi çeperindeki dik yamaçlar jeolojik yönden ilginç olmakla birlikte dağcıların tırmanma için kullandıkları alanlardır. Ayrıca yamaçlarda teras şeklinde traverten oluşumları da görülmektedir. Bunların yanında sahip olduğu beş karasal ve bir sucul ekosistem tipi ile, zengin flora çeşitliliği ve yaşama ortamı ile zengin fauna yapısı sunmaktadır. Doğa yürüyüş güzergahları, kamp ve günübirlik kullanım alanları ise çeşitli rekreasyon faaliyetlerine olanak sağlamaktadır. 

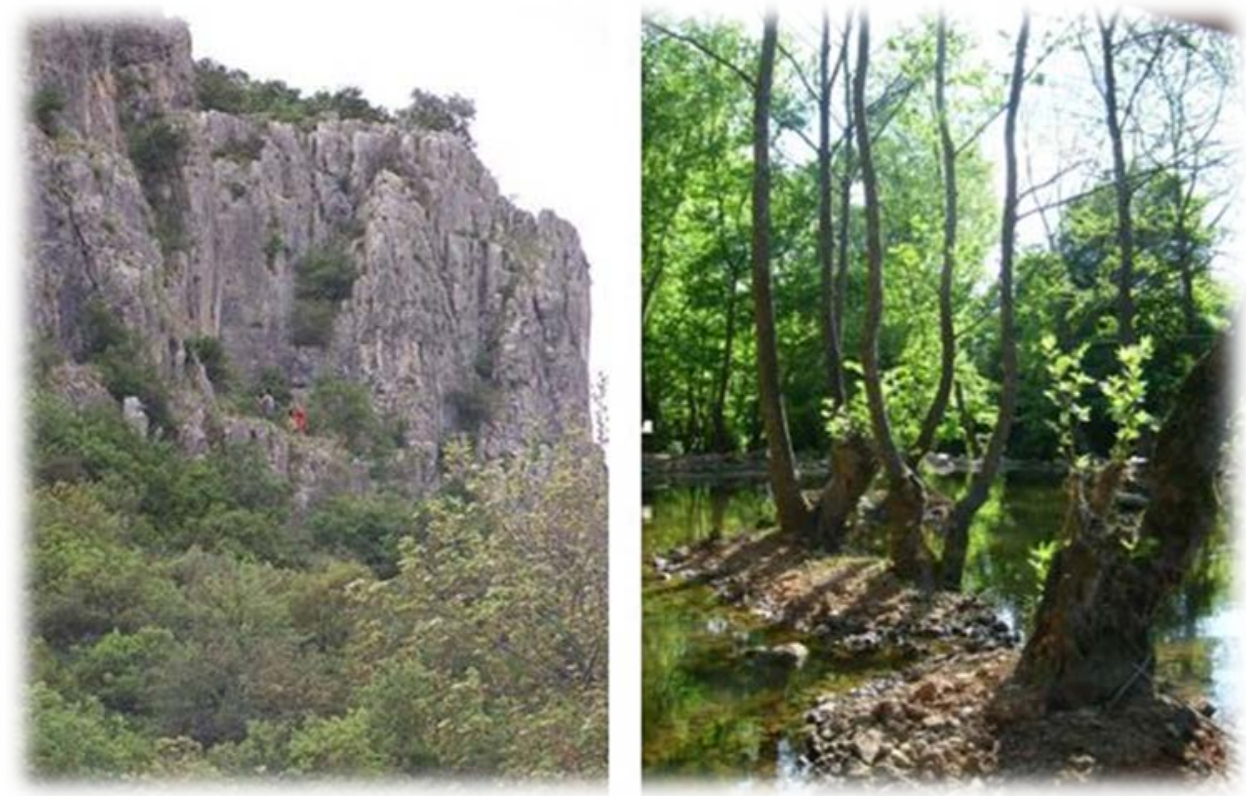

Fot. 1: Ballıkayalar Tabiat Parkı kaynak değerlerinden bir görünüm

(Fotoğraflar yazarlar tarafından çekilmiştir.)

Tabiat Parkı ilan edilmeden önce, 1970-1980 yılları arasında Ballıkayalar Vadisi dağcılık ve kaya tırmanışları amacı ile tanınmaya başlamıştır (Palut \& Aydıngün, 2002). Sanayi alanları ve ulaşım güzergahlarının tehdidi altında olan alanın, sahip olduğu bu değerlerin korunması ve gelecek kuşaklara aktarılması amacıyla 1992 yılında Türkiye Çevre Koruma ve Yeşillendirme Kurumu (TÇKYK) bünyesinde bir çalışma grubu oluşturulmuş, "Sürdürülebilir Kullanma" modeli altında, alanı kullanıma kapatmadan, korunması, gerekli bilimsel çalışmaların tamamlanmasını takiben bir plan yapılması ve alanın halkın kullanımına sunulması görüşü benimsenmiştir (Türkiye Çevre Koruma ve Yeşillendirme Kurumu, 1994). Orman Bakanlığı Milli Parklar ve Av-Yaban Hayatı Genel Müdürlüğü nezdinde TÇKYK tarafından yürütülen çalışmalar doğrultusunda Aralık 1993'de alanın Tabiat Parkı olarak ilan edilmesi için görüş birliğine varılmış ve 1994 yılında Orman Bakanlığı Milli Parklar ve Av-Yaban Hayatı Genel Müdürlüğü ile TÇKYK arasında imzalanan protokol doğrultusunda, TÇKYK alana ilişkin plan çalışmalarını hazırlamış, Genel Müdürlük alanın Tabiat Parkı ilan edilmesi ile ilgili süreci yürütmüştür (T.C. Orman Bakanlığı Milli Parklar ve Av-Yaban Hayatı Genel Müdürlüğü, 2003). Bu sürecin sonunda, 6 Eylül 1995 tarih ve 22396 sayılı Resmi Gazetede yayınlanan, 21 Temmuz 1995 tarihli 7144 sayılı Bakanlar Kurulu kararı ile Ballıkayalar Vadisini de içine alan ve sınırları söz konusu Resmi Gazetede belirtilen 1603 ha. alan "Ballıkayalar Tabiat Parkı" olarak ilan edilmiştir (T.C. Çevre ve Orman Bakanlığı Doğa Koruma ve Milli Parklar Genel Müdürlüğü, 2004).

Bölgede, İstanbul 2 numaralı Koruma Kurulu'nun 24.01.1995 gün ve 3663 sayılı kararı ile belirlenen, Ballıkayalar Tabiat Parkını içine alan ve 2980 ha. alanı kapsayan 1. derece Doğal Sit sınırı, Bursa Kültür ve Tabiat Varlıklarını Koruma Kurulu'nun 13.11.2003 tarih ve 10157 sayılı kararı ile 06.09.1995 tarihinde belirlenen Tabiat Parkı sınırlarını esas alacak şekilde yeniden düzenlenmiştir. Bu uygulama ile; 1 . derece doğal sit alanı sınırı daraltılarak Tabiat Parkı sınırı ile çakıştırımış, böylece Ballıkayalar Tabiat Parkı sınırı aynı zamanda 1. Derece doğal sit alanı sınırı haline getirilmiş, bununla birlikte 1. derece doğal sit kapsamını dışına çıkartılan Tavşanlı Deresi havzasının Tabiat Parkı'nın güney sınırına bitişik yaklaşık 243 ha.'lık alan 3. derece Doğal Sit statüsü ile korunmaya devam edilmiştir. 


\subsection{Ballıkayalar Tabiat Parkı UDGP}

Ballıkayalar Tabiat Parkı ile ilgili ilk planlama çalışması 2005 yılında Çevre ve Orman Bakanlığı, Doğa Koruma ve Milli Parklar Genel Müdürlüğü (günümüzde T.C. Orman ve Su işleri Bakanlığı Doğa Koruma ve Milli Parklar Genel Müdürlüğü) tarafından yaptırılan "Ballıkayalar Tabiat Parkı 1/25000 Ölçekli Uzun Devreli Gelişme Planı" nı olmuştur (Şekil 8).

UDGP nında genel ve mutlak koruma alanı, sınırlı kullanım alanı, kontrollü kullanım alanı olarak tanımlanan 3 bölge için plan kararları geliştirilmiştir. Genel kullanım kararları; park içi ulaşım, giriş kontrol noktaları, otoparklar, idare - ziyaretçi ve tanıtım merkezi, manzara seyir noktaları, tur güzergahları, günübirlik kullanım alanları, çadırlı kamp alanları, geleneksel ürün satış noktaları konularını içermekte, ayrıca 3 bölge için özel kullanım kararları getirilmektedir. Planda bunlara ek olarak genel ve özel hükümler yanında, öneriler ile parkın yönetim ve organizasyonuna yer verilmektedir.

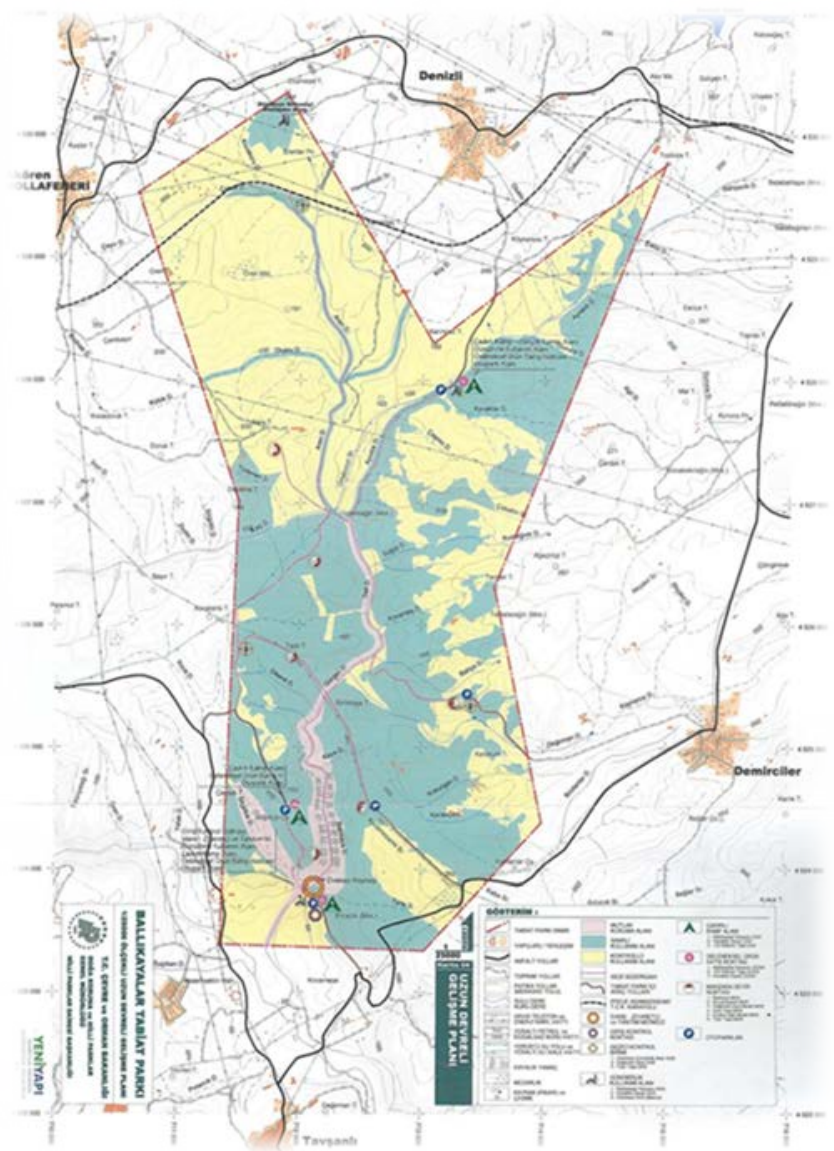

Şekil 8: Ballıkayalar Tabiat Parkı 1/25000 ölçekli Uzun Devreli Gelişim Planı (UDGP)

(T.C. Çevre ve Orman Bakanlığı Doğa Koruma ve Milli Parklar Genel Müdürlüğü, 2004)

Planda mutlak koruma alanı pembe bölge olarak gösterilmekte ve alanın ana kaynak değerlerinin olduğu bölgeyi kapsamaktadır. Bu bölgede kaya tırmanışı ve belirlenen tur güzergahında yapılacak yürüyüşler dışında hiç bir faaliyete izin verilmez. Sınırlı kullanım alanı planda mavi renkle, kontrollü kullanım alanı sarı renkle gösterilen bölgedir. Bu bölgelerde dokuz ayrı alanda kullanım kararı alınmıştır. Bu alanlar; Ballıkayalar Kanyonu, 159 Rakımlı Tepe, Kocamezarlık, Değirmendere Mevkii, Kavaklar Deresi, Kara Tepe, Üçdere Ağzı Mevkii, Taşlı Tepe ve Düzmeşe Günübirlik 
Kullanım Alanıdır. Bu alanlarda, giriş kontrol noktası, gezici kontrol birimleri, otoparklar, idare - ziyaretçi ve tanıtım merkezi, manzara seyir noktaları, tur güzergahları, günübirlik kullanım alanları, çadırlı kamp alanları, geleneksel ürün satış noktaları kullanımlarına yerin sınırlıklarına ve olanaklarına uygun olacak şekilde yer verilmektedir.

\subsection{Ballıkayalar Tabiat Parkı koruma amaçıı imar planı amaç ve kapsamı}

Ballıkayalar Tabiat Parkı Uzun Devreli Gelişim Planı (UDGP) 'nda kullanım kararı alınan dokuz alandan ikisi birleştirilmek şartıyla beş alana ilişkin Koruma Amaçı İmar Planı hazırlanması talep edilmiştir. Böylece dört planlama bölgesi için yapılaşma koşullarının belirlenmesine karar verilmiştir.

Koruma Amaçlı İmar Planı yapılacak olan bu dört bölge sırasıyla şöyle sıralanmaktadır:

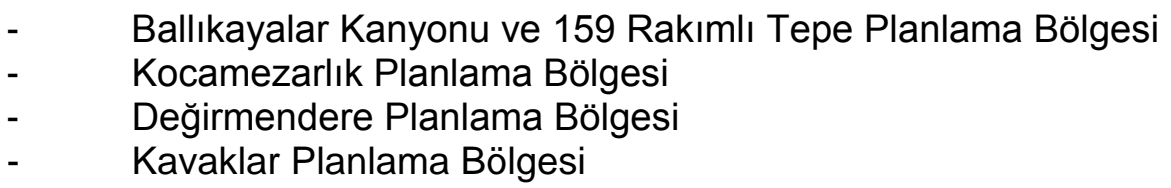

Planlama bölgelerinin Tabiat Parkı içindeki konumları Şekil 9 da gösterilmektedir. Ayrıca UDGP'de gezici kontrol birimi önerilen ve mevcutta günübirlik kullanım alanı olarak kullanılan Düzmeşe Günübirlik Kullanım Alanı, gezici kontrol birimi ve manzara seyir noktası önerilen Taşı ı Tepe, manzara seyir noktaları önerilen Kara Tepe, Üçdere Ağzı Mevkii Planlama Bölgeleri için de analiz çalışmaları yapılmış, ancak planlama kararları geliştirilmemiştir.

Söz konusu planlama bölgeleri için Ballıkayalar Tabiat Parkı Koruma Amaçlı İmar Planı'nın amacı; Ballıkayalar Tabiat Parkı Uzun Devreli Gelişme Planı kararları doğrultusunda, kullanım biçimleri, donatı alanları ve ulaşım sistemine yönelik, planlama alanları bütününde (dört planlama bölgesi) sahip oldukları jeomorfolojik, biyolojik (flora, fauna, ekolojik yapı), jeolojik, peyzaj ve rekreasyonel kaynak değerlerinin korumakullanma dengesi içinde devamlılığını ve gelecek nesillere aktarılmasını sağlayacak düzenlemelerin yapılması, uygulanma koşul, araç ve yöntemlerinin geliştirilmesi olarak ortaya konmuştur.

Plan bölgelerinin konumları ve UDGP'nda belirtilen kullanımları şu şekildedir:

Ballıkayalar Kanyonu ve 159 Rakımlı Tepe Planlama Bölgesi; Tabiat Parkı'nın güneyinde ve Tabiat Parkı'nın karakterini oluşturan kanyonun girişi niteliğinde bir konumdadır. Bölge, yaklaşık olarak toplam 49 ha. olup, UDGP'nda giriş kontrol noktası, araç yolu, otoparklar, idare - ziyaretçi ve tanıtım merkezi, manzara seyir noktası, tur güzergahı, günübirlik kullanım alanı, çadırlı kamp alanları, geleneksel ürün satış noktaları kullanımları öngörülmektedir.

Kocamezarlık Planlama Bölgesi; Tabiat Park alanının güneydoğusunda yer alan ve mevcutta tarımsal kullanım ve çalılık, bozuk - baltalık meşe ve maki-yalancı maki topluluklarının bulunduğu kısımdır. En yakın yerleşim yeri, güneyinde yer alan Tavşanlı Köyü'dür. Planlama Bölgesi yaklaşık 7 ha. dır. UDGP'nda bölgede, manzara seyir noktası, araçyolu, otopark ve tur güzergahı önerilmektedir.

Değirmendere Planlama Bölgesi, Tabiat Park alanının doğusunda yer alan ve mevcutta meyve bahçelerinin bulunduğu bölgesidir. En yakın yerleşim yeri, doğusunda yer alan Demirciler Köyü'dür. Planlama Bölgesi yaklaşık olarak 7 ha.'lık bir alana 
sahiptir. UDGP'nda, gezici kontrol birimi, araç yolu, otopark, manzara seyir noktası, tur güzergahı kullanımları öngörülmektedir.

Kavaklar Deresi Planlama Bölgesi, Tabiat Park alanının kuzeydoğusunda yer alan ve mevcutta yer yer tarım alanları, yamaçlarda ise karışık biçimde çalılık, bozuk - baltalık meşe ve maki toplulukları ile çayır-otlak vb. ekilmeyen arazilerin bulunduğu bölgesidir. En yakın yerleşim yeri, kuzeyinde yer alan Denizli Köyü'dür. Planlama Bölgesi yaklaşık olarak 27 h.'ık bir alana sahip olup, UDGP'nda araç yolu, otopark, tur güzergahı, günübirlik kullanım alanı, çadırlı kamp alanı, geleneksel ürün satış noktası kullanımları önerilmektedir.

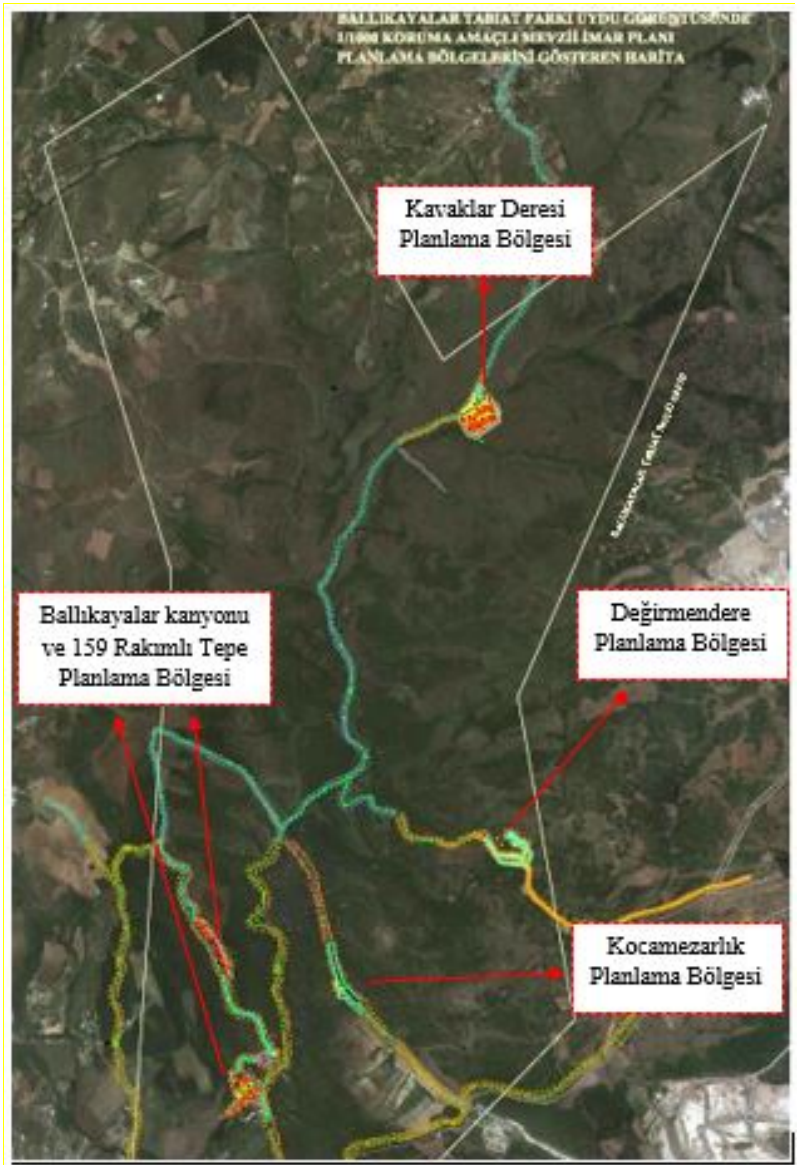

Şekil 9: Ballıkayalar Tabiat Parkı 4 planlama bölgesinin konumları

\subsection{Ballıkayalar Tabiat Parkı koruma amaçlı imar planlama çalışması}

Ballıkayalar Tabiat Parkı koruma amaçlı imar planlama çalışması; literatür ve diğer ülke örnek incelemesi, alan analiz ve sentez çalışması, plan ve plan kararlarının geliştirilmesini içeren üç aşamadan oluşmaktadır.

\section{I.Aşama: Literatür ve Diğer Ülke Örnek İncelemesi}

Konu ile ilgili yapılan bilimsel ve uygulamadaki çalışmaların araştırılması ve incelemesi ile tabiat parkı planlamasının ülkeden ülkeye farklılık gösterdiği anlaşılmıştır (Lowry, 1999, Province of British Colombia Ministry of Environment Lands and Parks, 1998, Stockdalea \& Barker, 2009, U.S. Department of the Interior, National Park Service, 1993, Zhou \& Grumbine 2011). Mevzuatlarına ve düzenlemelerine göre bazı ülkelerde geleneksel yöntemler izlenirken bazı ülkelerde de özel tasarım rehberleri aracılığıyla 
koruma-kullanma dengesinin sağlandığı planlama ve/veya tasarım çalışmaları yapıldığı tespit edilmiştir. Bu kapsamda, Kanada British Columbia bölgesinin "Park Design Guidelines \& Data" başıkılı park tasarım rehberi detaylı bir şekilde incelenmiş ve değerlendirilmiştir. Bu değerlendirme sonucunda her ne kadar ülkemizde tabiat parkı planlamasında tasarım rehberlerine yer verilmese de, çalışmanın planlama ve tasarım arakesitinde yürütülerek plan ve plan kararları geliştirilmesi gerekliliği belirlenmiştir.

\section{Alan Analizi ve Sentez Çalışması}

$\mathrm{Bu}$ aşamada; planlama bölgeleri analiz çalışmaları yapılmış, sentez haritaları oluşturulmuş ve sonucunda dört alt bölgeye yönelik sorunlar ve olanaklar tespit edilmiştir.

Ballıkayalar Kanyonu ve 159 Rakımlı Tepe Planlama Bölgesi'nde; tabiat parkı fonksiyonlarına engel olabilecek dört farklı konu tespit edilmiştir. İlk konu, alan içerisinden kuzeybatı- güneydoğu doğrultulu geçen fay hattıdır. Bu alan, özellikle yapılaşma içeren tabiat parkı fonksiyonlarının konumlanamayacağı alan olarak gözükmektedir. İkinci olarak, alanın çok sınırlı açık alan kullanımlarını içerebilecek yüksek eğimli bir arazi niteliğinde olmasıdır. Ballıkayalar Kanyonu'nun yamaçları ve kanyon girişinin doğu kısmında kalan tepeler \%30 ve üstü eğime sahip bölgelerdir. Üçüncü husus, alanın güney kısmında derenin doğu kısmında kalan alanların büyük bir bölümü şahsa ait özel mülkiyet alanlarıdır. Bu özel mülkiyet durumu alan genelinde tabiat parkının gereksinimi olan fonksiyonların yer seçmesinde problem teşkil etmektedir. Meşe ve Karaçam korularının oluşturduğu vejetasyon taşıdığı doğal değerler bağlamında korunması gereken değerler bakımından, yapılaşma gerektiren fonksiyonlar için dördüncü kesin kısıtı oluşturmuştur. Kanyonun batı yamaçları (alanın kuzey kısmı) bu vejetasyona sahip alanlardır. 159 Rakımlı Tepede, kuzey kısmında özel mülkiyetli arazilerin bulunduğu, içerisinde kuzey güney uzanımlı Meşe- Karaçam vejetasyonu olarak nitelendirilebilecek ağaçlık alan arazi kullanımının olduğu, özellikle Ballıkayalar kanyonu manzaralı güney kesiminde de yüksek eğimli alanların bulunduğu anlaşılmaktadır (Harita 1). 


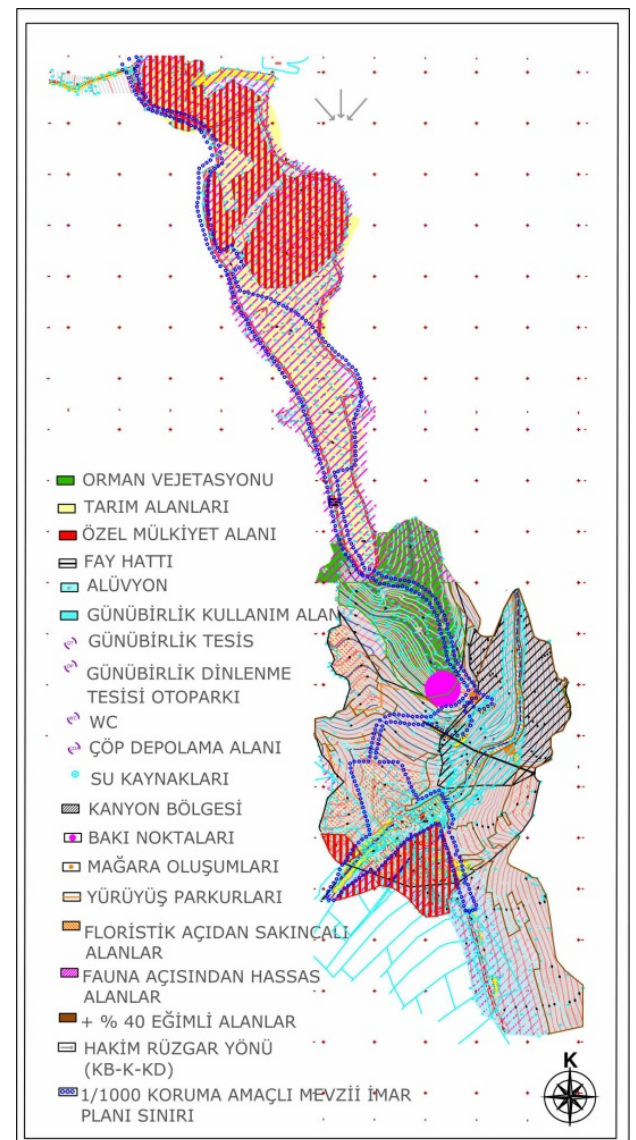

Harita 1: Ballıkayalar Kanyonu ve 159 Rakımlı Tepe Planlama Bölgesi sentezi

Kocamezarlık Planlama Bölgesi'nde tabiat parkı gereksinimlerine ve 1/25000'lik Uzun Devreli Gelişim Planı'nda belirtilen bölgeye yönelik belirlenen fonksiyonlara ilşikin baskın bir kısıt bulunmamakla beraber sadece bölgenin güneyinde küçük bir kesimde özel mülkiyette araziler yer almaktadır (Harita 2).

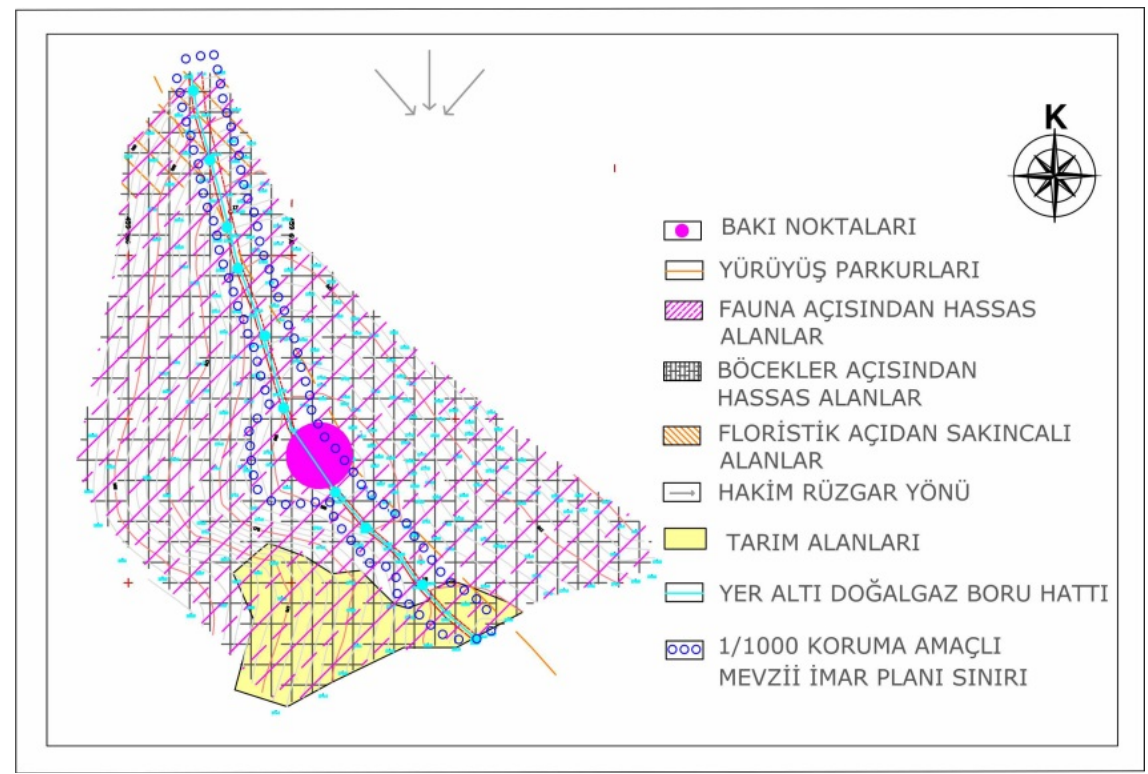

Harita 2: Kocamezarlık Planlama Bölgesi sentezi 
Değirmendere Planlama Bölgesi için, alan içerisinde dört farklı bölgede bulunan özel mülkiyetli araziler ve alanın güneyinde bulunan yüksek eğimli (\% 30'un üstü) bir bölge planlama bölgesindeki yapılacak olan plan çalışmasında önemli kısıtlar olarak gözükmektedir (Harita 3).

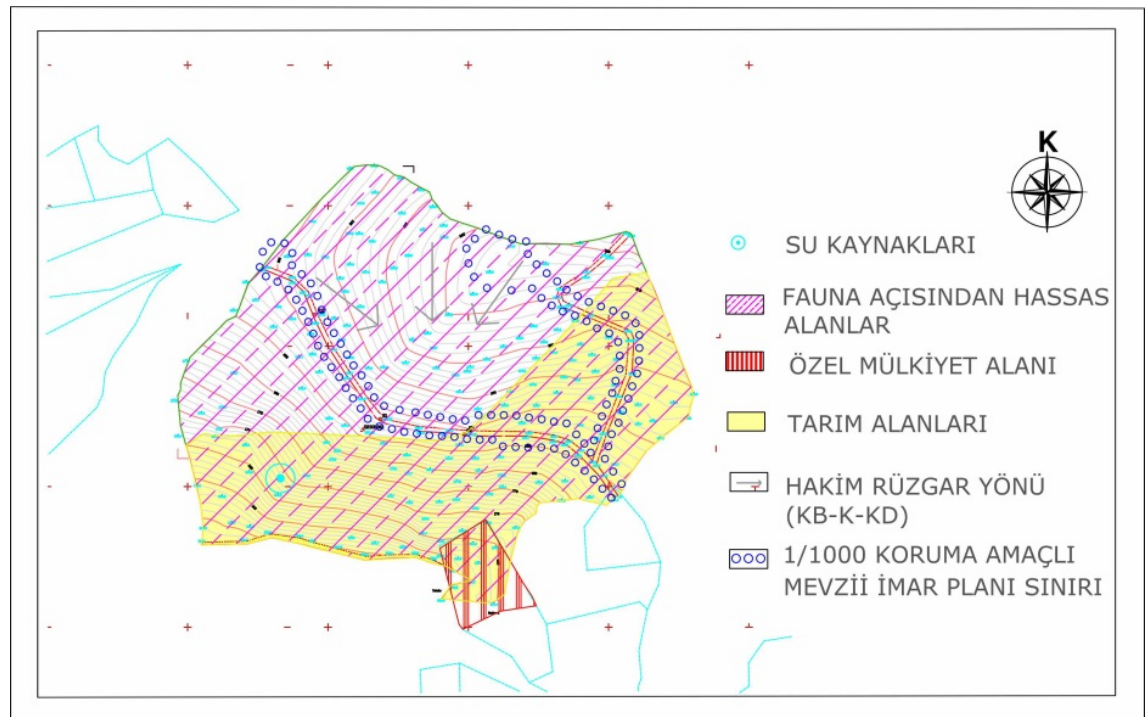

Harita 3: Değirmendere Planlama Bölgesi sentezi

Kavaklar Planlama Bölgesi'nin kuzey doğu- güney batı yönlü sınırını oluşturan Kavaklar Deresi, hattı boyunca yakın çevresinde alüvyon birikimli alanlar oluşturmuştur. Alüvyon birikimli bu alanlar tabiat parkının gerektirdiği kullanım fonksiyonları açısından yapılaşma ve konaklama gibi kullanımlar için risk oluşturduğu için sakıncalı bir alan konumundadır. Özel mülkiyetli araziler alanın güney kesiminde büyük bir kısımda bulunmaktadır. Ayrıca alan bütününde parça parka ve irili ufaklı yüksek eğimli alanlar bulunmaktadır (Harita 4).

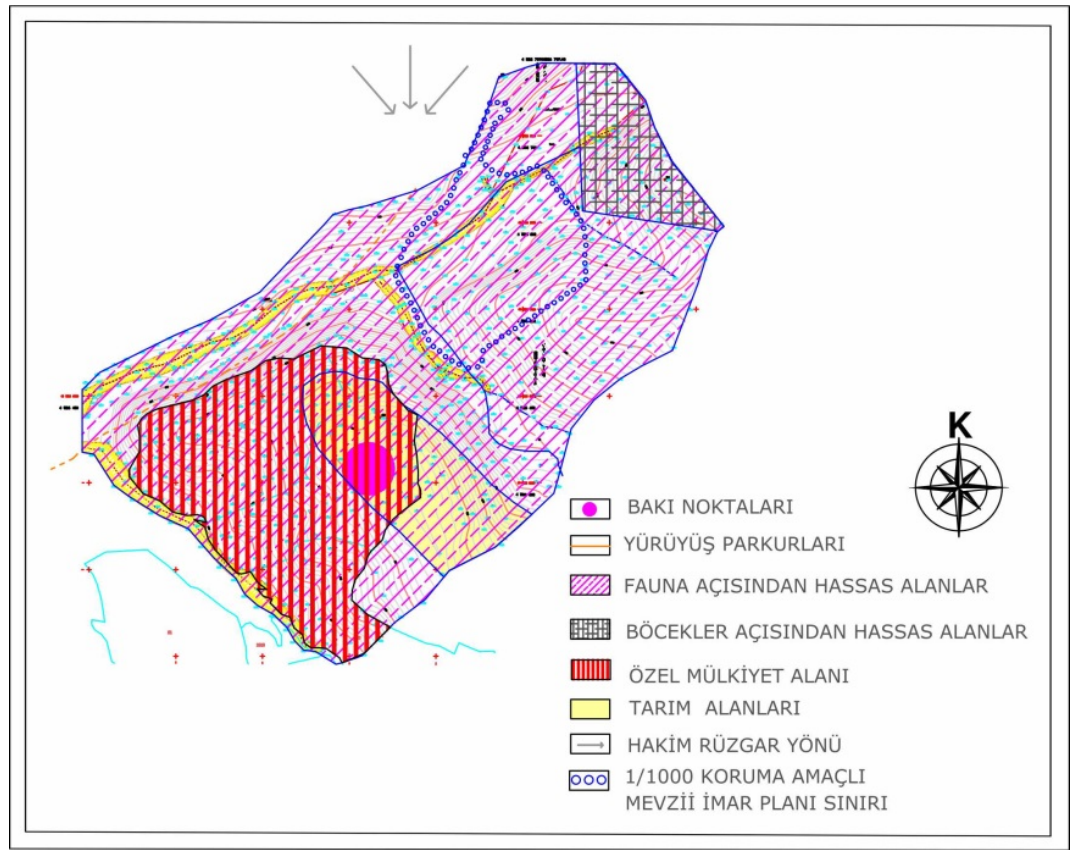

Harita 4: Kavaklar Planlama Bölgesi sentezi 
Ballıkayalar Tabiat Parkı Koruma Amaçlı İmar Planı Planlama Bölgeleri için oluşturulan dört sentez harita ve analiz değerlendirmeleri yedi başlıktan meydana gelen "sorunlar ve olanaklar" tablosunda biraraya getirilmiştir. Bu başlıklar; (1) Sınırlar ve idari yapı, (2) Arazi Kullanımı ve Teknik Altyapı, (3) Mülkiyet ve Orman Kadastrosu, (4) Fiziki Doğal Sınırlayıcılar, (5) Doğal- Rekreasyon Yapısı, (6) Jeolojik- Jeomorfolojik- TopografikHidrolojik ve Hidrojeolojik Yapı, (7) Ekolojik- Biyolojik ve Toprak Yapısı'ndan oluşmaktadır (Tablo 2). 
Türkiye'de Tabiat Parkları Koruma Amaçıı İmar Planlama Süreci: Ballıkayalar Tabiat Parkı Deneyimi Conservation Oriented Development Planning Process in Turkey: Ballıkayalar Natural Park Experience

Tablo 2. Ballıkayalar Tabiat Parkı Koruma Amaçlı İmar Planı Planlama Bölgeleri sorunları ve olanakları

\begin{tabular}{|c|c|c|c|c|c|c|c|c|}
\hline & \multicolumn{2}{|c|}{ Ballıkayalar Kanyonu ve 159 Rakımlı Tepe } & \multicolumn{2}{|l|}{ Kocamezarlık } & \multicolumn{2}{|l|}{ Değirmendere } & \multicolumn{2}{|l|}{ Kavaklar Deresi } \\
\hline & Sorunlar & Olanaklar & Sorunlar & Olanaklar & Sorunlar & Olanaklar & Sorunlar & Olanaklar \\
\hline $\begin{array}{l}\text { Sinırlar ve } \\
\text { İdari Yapı }\end{array}$ & $\begin{array}{l}\text { - sınırların algılanmaması } \\
\text { - denetim zorluğu }\end{array}$ & $\begin{array}{l}\text { - üst ölçek plan } \\
\text { varlığı } \\
\text { - 1. Derece doğal } \\
\text { sit alanı }\end{array}$ & $\begin{array}{l}\text { - sınırların } \\
\text { algılanmaması } \\
\text { - çekim kuvveti } \\
\text { eksikliği } \\
\text { - denetim zorluğu }\end{array}$ & $\begin{array}{l}\text { - üst ölçek plan } \\
\text { varlığı } \\
-1 \text {. Derece doğal sit } \\
\text { alanı }\end{array}$ & $\begin{array}{l}\text { - sınırların algılanmaması } \\
\text { - çekim kuvveti eksikliği } \\
\text { - denetim zorluğu }\end{array}$ & $\begin{array}{l}\text { - üst ölçek plan } \\
\text { varlığı } \\
\text { - 1. Derece doğal } \\
\text { sit alanı }\end{array}$ & $\begin{array}{l}\text { - sınırların } \\
\text { algılanmaması } \\
\text { - denetim zorluğu }\end{array}$ & $\begin{array}{l}\text { - üst ölçek } \\
\text { plan varlığı } \\
\text { - 1. Derece } \\
\text { doğal sit alanı }\end{array}$ \\
\hline $\begin{array}{l}\text { Arazi } \\
\text { Kullanımı ve } \\
\text { Teknik Altyapı }\end{array}$ & $\begin{array}{l}\text {-yakındaki sanayi tesisleri ve/veya OSB } \\
\text { varlığı } \\
\text {-çevredeki yerleşim alanları varlığı } \\
\text {-yoğun antropojenik kullanım baskısı } \\
\text {-yetersiz atık su sistemi } \\
\text {-derelere yapılan fabrika deşariları } \\
\text {-günübirlikçilerin çöplerinin } \\
\text { toplanmasındaki yetersizlik } \\
\text {-Gebze çöplüğünden kaynaklı koku ve } \\
\text { yeraltı suyu problemi } \\
\text {-Yoğun zamanlarda otopark problemi }\end{array}$ & $\begin{array}{l}\text {-Yeşil alan } \\
\text { intiyacı } \\
\text {-Ulaşılabilirlik }\end{array}$ & $\begin{array}{l}\text {-yakındaki sanayi } \\
\text { tesisleri ve/veya } \\
\text { OSB varlığı } \\
\text {-yoğun } \\
\text { antropojenik } \\
\text { kullanım baskısı } \\
\text {-doğal gaz boru } \\
\text { hattının varlığı }\end{array}$ & -Yeşil alan intiyacı & & $\begin{array}{l}\text {-Yeşil alan } \\
\text { intiyacı }\end{array}$ & $\begin{array}{l}\text {-yakındaki sanayi } \\
\text { tesisleri ve/veya } \\
\text { OSB varlığı } \\
\text {-derelere yapılan } \\
\text { fabrika deşariları } \\
\text {-Ulaşılabililik } \\
\text { problemi }\end{array}$ & $\begin{array}{l}\text {-Yessil alan } \\
\text { intiyacı }\end{array}$ \\
\hline $\begin{array}{l}\text { Mülkiyet ve } \\
\text { Orman } \\
\text { Kadastrosu }\end{array}$ & -özel mülkiyet varlığı & $\begin{array}{l}\text {-Ana kaynak } \\
\text { değerinin orman } \\
\text { statüsünde } \\
\text { bulunması }\end{array}$ & & & -özel mülkiyet varlığı & & & \\
\hline $\begin{array}{l}\text { Fiziki Doğal } \\
\text { Sınırlayıcılar }\end{array}$ & $\begin{array}{l}\text {-Bölge nüfusunun artması } \\
\text {-Sanayi kaynaklı tarımsal faaliyetlerdeki } \\
\text { azalma } \\
\text {-Sanayi yoğunluğu sebebiyle Organik } \\
\text { Tarım yapılamaması } \\
\text {-Orman tahribatı } \\
\text {-Kaçak avlanma ve zehirleme } \\
\text {-Orman Amenajman Planı }\end{array}$ & $\begin{array}{l}\text {-Mollafenaride } \\
\text { bulunan tarım } \\
\text { Kredi } \\
\text { Kooperatifinin } \\
\text { varlığı } \\
\text {-Bağcılık } \\
\text { çalışmalarındaki } \\
\text { gelişmeler } \\
\end{array}$ & $\begin{array}{l}\text {-Bölge nüfusunun } \\
\text { artması } \\
\text {-Sanayi yoğunluğu } \\
\text { sebebiyle ı Organik } \\
\text { Tarım } \\
\text { yapılamaması } \\
\text {-yakındaki OSB } \\
\text { varlığı }\end{array}$ & $\begin{array}{l}\text {-Mollafenaride } \\
\text { bulunan Tarım Kredi } \\
\text { Kooperatifinin varlığı }\end{array}$ & $\begin{array}{l}\text {-Bölge nüfusunun artması } \\
\text {-Sanayi kaynaklı tarımsal } \\
\text { faaliyetlerdeki azalma } \\
\text {-Sanayi yoğunluğu sebebiyle } \\
\text { Organik Tarım yapıımaması } \\
\text {-Orman tahribatı } \\
\text {-Kaçak avlanma ve zehirleme } \\
\text {-yakındaki OSB varlı̆ı }\end{array}$ & $\begin{array}{l}\text {-Mollafenaride } \\
\text { bulunan tarım } \\
\text { Kredi } \\
\text { Kooperatifinin } \\
\text { varlığı }\end{array}$ & $\begin{array}{l}\text {-Bölge nüfusunun } \\
\text { artması } \\
\text {-Sanayi yoğunluğu } \\
\text { sebebiyle Organik } \\
\text { Tarım yapılamaması } \\
\text {-Kaçak avlanma ve } \\
\text { zehirleme } \\
\text {-yakındaki OSB } \\
\text { varlığı }\end{array}$ & $\begin{array}{l}\text {-Mollafenaride } \\
\text { bulunan tarım } \\
\text { Kredi } \\
\text { Kooperatifinin } \\
\text { varlığı }\end{array}$ \\
\hline $\begin{array}{l}\text { Doğal- } \\
\text { Rekreasyon } \\
\text { Yapısı } \\
\end{array}$ & $\begin{array}{l}\text {-Kontrolsüz rekreasyonel faaliyetler } \\
\text {-Niteliksiz günübirlik tesisle }\end{array}$ & $\begin{array}{l}\text {-Kaya tırmanış̧ı } \\
\text { için uygun doğal } \\
\text { yapı }\end{array}$ & & & $\begin{array}{l}\text {-Doğal gaz hattından } \\
\text { kaynaklı doğa tahribatı }\end{array}$ & & & \\
\hline $\begin{array}{l}\text { Jeoloji- } \\
\text { jeomorfoloji- } \\
\text { Topografya- } \\
\text { Hidrolik- } \\
\text { Hidrojeoloji }\end{array}$ & -Kaya düşmesi riskinin varlığı & $\begin{array}{l}\text {-Jeolojik } \\
\text { formasyonun } \\
\text { çeşitliliği } \\
\text {-Jeomorfolojik } \\
\text { oluşumlar }\end{array}$ & & $\begin{array}{l}\text {-Jeolojik } \\
\text { formasyonun } \\
\text { çeşitliliği } \\
\text {-Jeomorfolojik } \\
\text { oluşumlar }\end{array}$ & & $\begin{array}{l}\text {-Jeolojik } \\
\text { formasyonun } \\
\text { çeşitliliği }\end{array}$ & $\begin{array}{l}\text {-Yerleşim ve } \\
\text { endüstri yapılarının } \\
\text { hidrolojik havza } \\
\text { içerisinde bulunması }\end{array}$ & $\begin{array}{l}\text {-Jeolojik } \\
\text { formasyonun } \\
\text { çeşitililiği }\end{array}$ \\
\hline $\begin{array}{l}\text { Ekoloji- } \\
\text { Biyoloji- } \\
\text { Toprak Yapısı }\end{array}$ & $\begin{array}{l}\text {-Uygun olmayan ağaçlandırma } \\
\text { çalışmaları } \\
\text {-Zararlı böcek türleri sayısındaki artış } \\
\text {-Fitoplanktonik Organizmaların Yüksek } \\
\text { Yoğunluğu } \\
\text {-Su erozyonu riski }\end{array}$ & $\begin{array}{l}\text {-Bağ- bahçe } \\
\text { tarımına elverişli } \\
\text { toprak yapısı }\end{array}$ & & & $\begin{array}{l}\text {-Zararlı böcek türleri } \\
\text { sayısındaki artış }\end{array}$ & & $\begin{array}{l}\text {-Zararlı böcek türleri } \\
\text { sayısındaki artış } \\
\text {-Su erozyonu riski }\end{array}$ & \\
\hline
\end{tabular}




\section{III.Aşama: Plan ve Plan Kararlarının Geliştirilmesi}

Ballıkayalar Tabiat Parkı Koruma Amaçlı İmar Planı amacına uygun olarak 1/5000 nazım ve 1/1000 ölçekli uygulama imar planlarında; sürdürülebilir, koruma-kullanma dengesine sahip, bölgedeki hızlı ve plansız kentsel ve sanayi gelişimine karşı ayakta duran bölgedeki kentsel ve civarındaki yarı kırsal yerleşmelerde yaşayan nüfusun giderek artan açık yeşil/ rekreasyon alan intiyaçlarına hizmet verecek, Tabiat Parkı'nın kaynak değerlerinin yakından tanınmasına imkan sağlayacak, doğa sevgisini ve doğada yaşama arzusunu güçlendirecek bir planlama anlayışı kapsamında aşağıdaki hedefler belirlenmiştir:

- Doğal değerlerin korunmasına ve devamlılığının sağlanmasına yönelik hedefler: Doğal habitatın ve ekolojik dengenin korunarak bölgedeki doğal, kaynak ve peyzaj değerlerinin üzerinden sürdürülebilirlik temelinin oluşturulması,

- Koruma-kullanma sürecinin geliştirilmesine yönelik hedefler: Mevcut değerleri koruyarak sürdürmeye yönelik kararları içeren bir süreç,

- Eğitim ve tanıtıma yönelik hedefler: Planlanan alanlarda önerilen kullanımların doğal yaşam ortamını tanıtıcı, ziyaretçileri bilgilendirici, doğa sevgisini ve doğa koruma bilincini arttırıcı nitelikte olması,

- Demografik- ekonomik ve sosyo-kültürel hedefler: Tabiat Parkı çevresinde bulanan yöre halkının ekonomik çıkarları korunarak koruma-kullanma dengesinin kurulması ve bölgede canlılığın sağlanması,

- Yönetsel hedefler: Hazırlanacak planın uygulanabilir nitelikteki kararlar getirmesi ve uygulanabilirliğin sağlanmasına yönelik idari yapılanmanın organize edilmesi.

Plan hedefleri doğrultusunda oluşturulan, planlama bölgelerini birbirine bağlayan 1/5000 ölçekli ulaşım bağlantıları (Harita 5) ve plan bölgelerini gösteren nazım imar planı ile planlama bölgelerine ilişkin 1/1000 ölçekli uygulama imar plan ve kararlarına aşağıda yer verilmektedir. Bu makalede planlar A3 kağıdına göre ölçeklendirilerek oluşturulan düzende yerleştirilmiştir. 


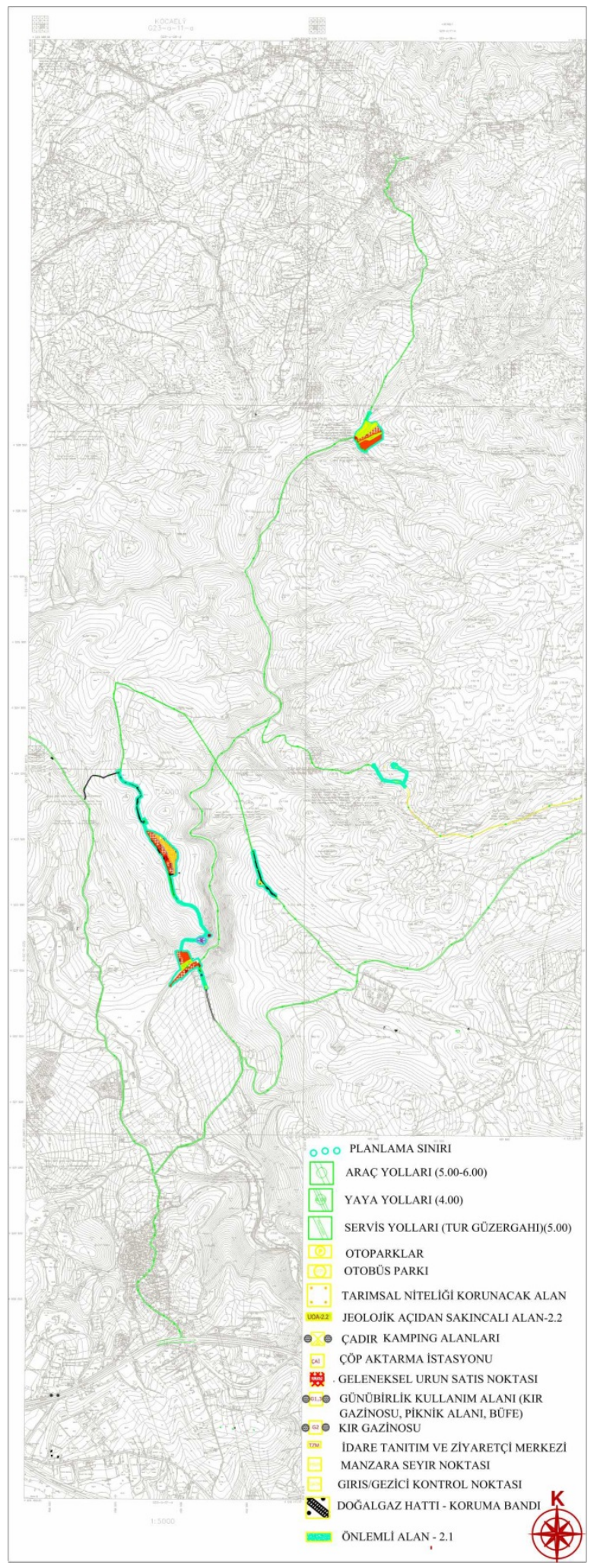

Harita 5: 1/5000 ölçekli ulaşım bağlantıları ve plan bölgelerini gösteren Nazım İmar Planı 
1/5000 ölçekli nazım imar planı dört alt bölgenin birbirine yaya ve taşıt bağlantılarını ve genel kullanımlarını göstermektedir. 1/1000 ölçekli koruma amaçlı uygulama imar planı ve planlama kararları her bölge için planlama tasarım arakesitinde geliştirilerek oluşturulmuştur.

\section{Ballıkayalar Kanyonu ve 159 Rakımlı Tepe Planlama Bölgesi Plan ve Plan Kararları;}

1/25000 ölçekli Ballıkayalar Tabiat Parkı Uzun Devreli Gelişim Planı'nda Ballıkayalar Kanyonu planlama bölgesi ile ilgili plan kararları uygulanmaktadır, ayrıca yine aynı planda bu bölge için;

- Taşıt yolu ve otopark (hem kanyon hem de 159 rakımlı tepede),

- Giriş kontrol noktası (sadece kanyon bölgesinde),

- $\quad$ İdare, ziyaretçi ve tanıtım merkezi (sadece kanyon bölgesinde),

- Geleneksel ürün satış noktası (hem kanyon hem de 159 rakımlı tepede),

- Günübirlik kullanım alanı (sadece kanyon bölgesinde),

- Çadırlı kamp alanı (hem kanyon hem de 159 rakımlı tepede),

- Manzara seyir noktası (sadece 159 rakımlı tepede kanyona bakar bölgelerde) kullanım fonksiyonları belirlenmiştir (Harita 6).

Bu fonksiyonlar "Mesire Yerleri Teknik İzahnamesi"nde belirtilen taşıma kapasiteleri doğrultusunda geliştirilmiştir.

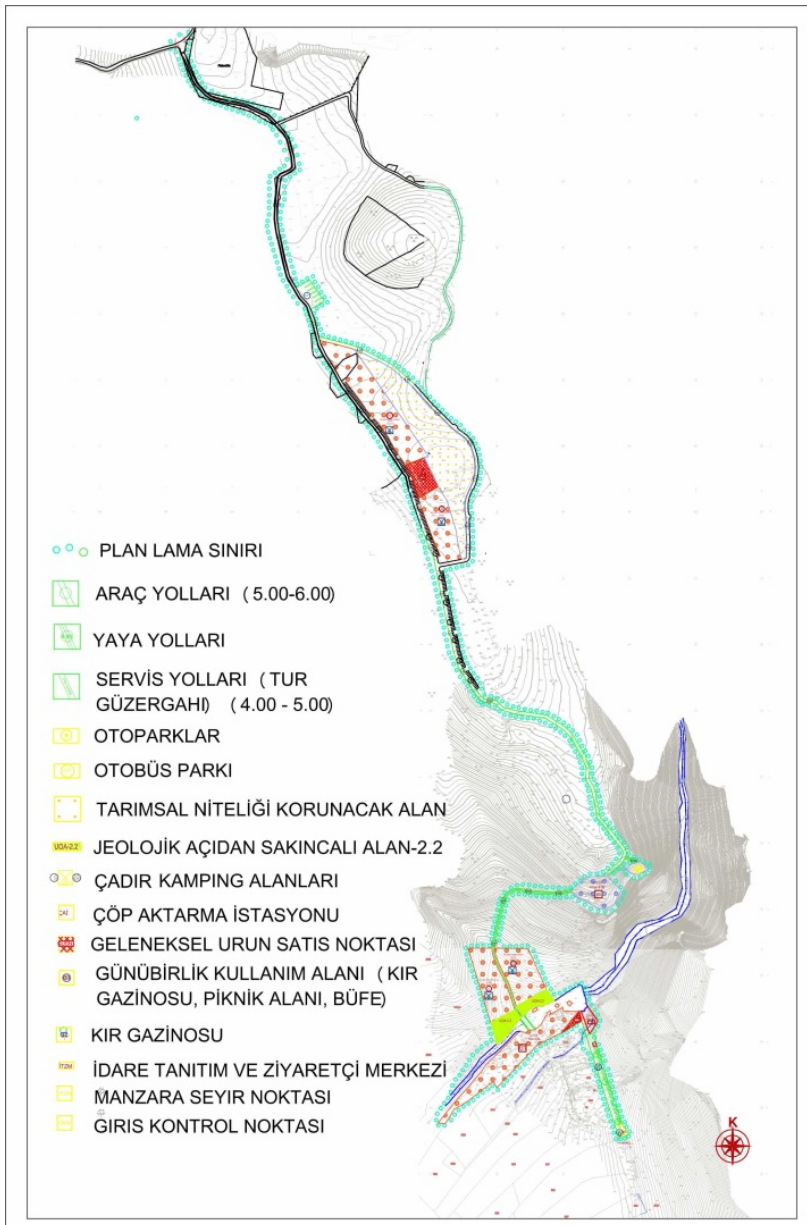

Harita 6: Ballıkayalar Kanyonu ve 159 Rakımlı Tepe Planlama Bölgesi 1/1000 ölçekli Uygulama İmar Planı 
Türkiye'de Tabiat Parkları Koruma Amaçlı İmar Planlama Süreci: Ballıkayalar Tabiat Parkı Deneyimi

Conservation Oriented Development Planning Process in Turkey: Ballıkayalar Natural Park Experience

Buna göre;

-Ballıkayalar Kanyonu ve 159 Rakımlı Tepe Planlama Bölgesi genelinde toplam 100 araçlık otopark alanı oluşturulmuştur.

-Giriş kontrol noktası olarak $6 \mathbf{m}^{2}$ 'yi geçmeyen tek bir birim olarak, alana giriş noktası olarak belirlenen bölgede planlanmıştır. Maksimum kat yüksekliği olarak $4.50 \mathrm{~m}$. belirlenmiştir.

-İdare, ziyaretçi ve tanıtım merkezi Ballıkayalar Tabiat Parkı bütününde sadece bir adet olarak giriş niteliğindeki Ballıkayalar Kanyon bölgesinde planlanmıştır, $500 \mathrm{~m}^{2}$ 'lik bir alan üzerinde düşünülen bu merkez $250 \mathrm{~m}^{2}$ 'yi geçmeyen bir yapı olarak düşünülmüştür. Hmaks (maksimum kat yüksekliği) olarak $4.50 \mathrm{~m}$. olarak belirlenen bu merkezin kanyon ve gölet ile görsel ve fiziki bir ilişkide olması esas olarak belirlenmiştir.

-Kanyon ve tepe bölgesinde ayrı ayrı olmak üzere iki alanda geleneksel ürün satış noktası (stant alanı) planlanmıştır. Tepe bölgesinde ve kanyon bölgesinde belirlenen alanlarda yapıların stantlar şeklinde taşınabilir ve hmaks. (maksimum kat yüksekliği) 4.50 m olarak belirlenmiştir. 6 $\mathrm{m}^{2}$ 'yi geçmeyen büyüklükte birimler olarak Kanyon kısmındaki birinci bölgede maksimum 4 adet stant birim ve 159 Rakımlı Tepe kısmındaki ikinci bölgede maksimum 25 adet stant birim düşünülmüştür.

-Günübirlik kullanım alanı olarak $7000 \mathrm{~m}^{2}$ 'lik bir alan Ballıkayalar Kanyon bölgesinde ayrılmıştır ve bu alan içerisinde alt kullanımlar (kır gazinosu, piknik alanı ve ortak kullanım alanları- spor tesisi, çocuk oyun alanı, otopark alanı, büfe, kır gazinosu ve tuvaletler-) bulunmaktadır. Bu kullanımlara ait özellikler "günübirlik kullanım alanları" başlığı altında detaylandırılmıştır. Günübirlik kullanım alanlarında maksimum yapılaşma alanı 569 m² $^{2}(2 * 250$ $\mathrm{m}^{2}$ 'lik kır gazinosu, $30 \mathrm{~m}^{2}$ 'lik tuvalet, $30 \mathrm{~m}^{2}$ 'lik ocak ve bulaşıkhane ve $9 \mathrm{~m}^{2}$ 'lik büfe) ve hmaks $4.50 \mathrm{~m}$. olarak belirlenmiştir. $7000 \mathrm{~m}^{2}$ 'lik toplam günübirlik kullanım alanının $1400 \mathrm{~m}^{2}$ 'lik kısmı yol ve yeşil alanlar için, $5000 \mathbf{~ m}^{2}$ 'lik kısmı piknik alanı (5 kişilik bir aile için 1 piknik masası ve $200 \mathrm{~m}^{2}$ 'lik alan düşünüldüğünde toplam 25 ailelik), $250 \mathbf{~ m}^{2}$ 'lik kır gazinosu, $150 \mathbf{~ m}^{2}$ 'lik açık spor alanı, $50 \mathrm{~m}^{2}$ 'lik açık çocuk oyun alanı, $30 \mathrm{~m}^{2}$ 'lik tuvalet ve giyinme birimleri, $20 \mathrm{~m}^{2}$ 'lik çamaşırhane ve bulaşıkhane, $9 \mathrm{~m}^{2}$ 'lik büfe ve $10 \mathrm{~m}^{2}$ 'lik çöp toplama alanı olarak belirlenmiştir.

-"Turizm Tesislerinin Belgelendirilmesine ve Niteliklerine İlişkin Yönetmelikte 23. Maddede çadırı kamp alanları ile ilgili olarak, 1 kamp ünitesinin 3 kişilik olarak, kampçı ünitesi başına 80 $\mathrm{m}^{2}$ 'lik bir alana ihtiyacı olduğu belirtilmiştir. Ballıkayalar Kanyonu ve 159 Rakımlı Tepe planlama bölgesinde on (10) adet ve herbiri $2000 \mathrm{~m}^{2}$ olan çadırlı kamp alanları tasarlanmıştır. Çadırlı kamp alanlarının 4 tanesi (toplam $8000 \mathrm{~m}^{2}$ 'lik 80 çadırlık ve 240 kişilik kısmı) Ballıkayalar kanyon bölgesinde, 6 tanesi (toplam 12000 m² 'lik 120 çadırlık ve 360 kişilik kısmı) 159 Rakımlı Tepe bölgesinde tasarlanmıştır.

Çadırlı kamp alanlarında, maksimum yapılaşma alanı $50 \mathrm{~m}^{2}$ (tuvaletler ve duş alanları $30 \mathrm{~m}^{2}$, $20 \mathrm{~m}^{2}$ çamaşırhane ve bulaşıkhane) ve hmaks (maksimum kat yüksekliği) $4.50 \mathrm{~m}$. belirlenmiştir. $2000 \mathrm{~m}^{2}$ 'lik bir alan içinde $400 \mathrm{~m}^{2}$ 'lik kısmı yol, yeşil alan ve ortak kullanım alanları (tuvaletler ve duş alanları $30 \mathrm{~m}^{2}$, yakacak deposu $8 \mathrm{~m}^{2}$, bulaşıkhane $10 \mathrm{~m}^{2}$, çamaşırhane $10 \mathrm{~m}^{2}$, çöp toplanma alanı $5 \mathrm{~m}^{2}$, su deposu $5 \mathrm{~m}^{2}$, ocak ve yeme pişirme alanı 12 $\mathrm{m}^{2}$ ), $1600 \mathrm{~m}^{2}$ 'lik alan ise kamp üniteleri (60 kişilk 20 kamp ünitesi) için düşünülmüştür.

Planlama bölgesinde manzara seyir noktaları 159 rakımlı tepe bölgesinde, kanyonu bakar konumda, seyir terasları şeklinde kanyonu ve göleti görebilecek alanlarda konumlandırılmıştır. Manzara seyir noktalarında ahşap platformlar, korkuluklar, yönlendirme işaretleri ve tanıtıcı panolardan oluşan sökülebilir ve taşınabilir birimler olarak düşünülmüştür. 


\section{Kocamezarlık Planlama Bölgesi Plan ve Plan Kararları}

1/25000 ölçekli Ballıkayalar Tabiat Parkı Uzun Devreli Gelişim Planı'nda Kocamezarlık planlama bölgesi "Sınırlı Kullanım Alanı" içerisinde yer almakta ve ilgili plan kararları uygulanmaktadır, ayrıca yine aynı planda bu bölge için;

- Taşıt yolu ve otopark,

- Manzara seyir noktası

kullanım fonksiyonları belirlenmiştir.

Kocamezarlık planlama bölgesinde otopark alanı olarak yaklaşık $750 \mathrm{~m}^{2}$ 'lik bir alanda 30 araçlık alan planlanmıştır. Alan içerisinde $1255 \mathrm{~m}^{2}$ alanda manzara seyir noktaları olarak kanyonu gören noktalar belirlenmiştir (Harita 7).

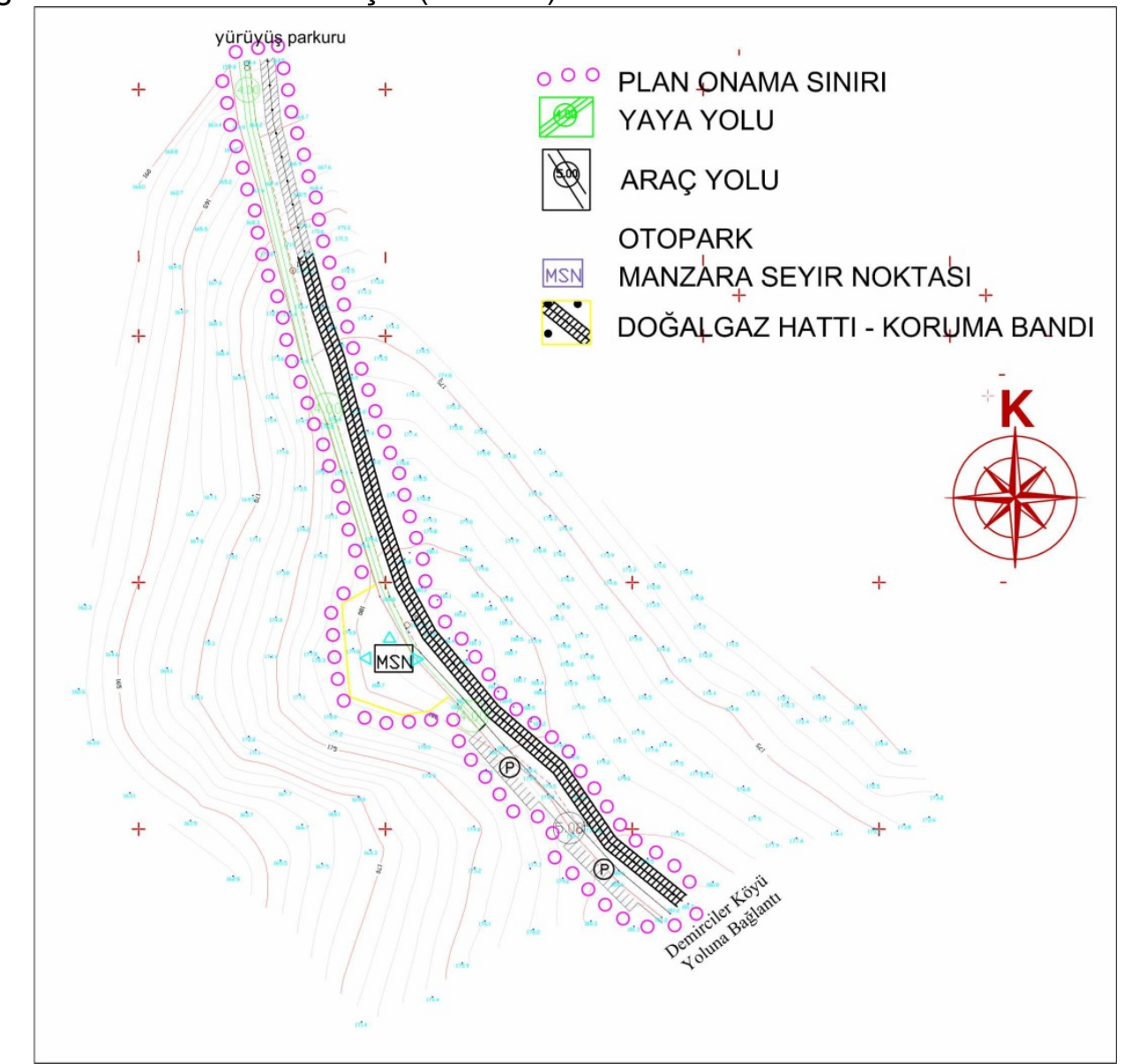

Harita 7: Kocamezarlık Mevkii Planlama Bölgesi 1/1000 ölçekli Uygulama İmar Planı

\section{Değirmendere Planlama Bölgesi Plan Kararları}

1/25000 ölçekli Ballıkayalar Tabiat Parkı Uzun Devreli Gelişim Planı'nda Değirmendere Mevkii planlama bölgesi ile ilgili olarak;

- Taşıt yolu ve otopark,

- Gezici kontrol birimi,

- Manzara seyir noktası

kullanım fonksiyonları belirlenmiştir. 


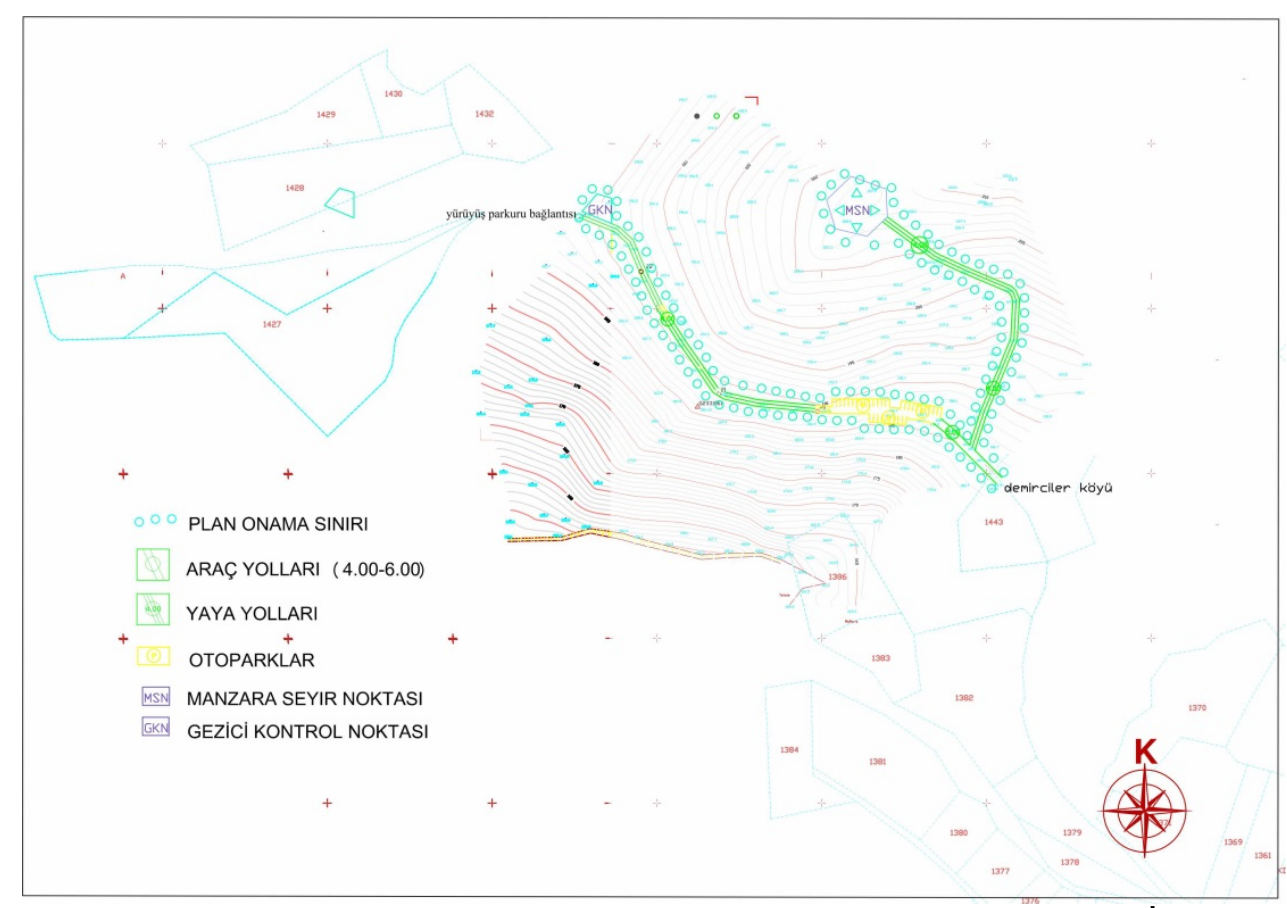

Harita 8: Değirmendere Mevkii Planlama Bölgesi 1/1000 ölçekli Uygulama İmar Planı

Değirmendere planlama bölgesinde yaklaşık 35 araçlık bir otopark alanı tasarlanmıştır. $6 \mathrm{~m}^{2}$ lik kontrol birimi olan gezici kontrol noktası $185 \mathrm{~m}^{2}$ olarak planlanmıştır. Manzara seyir noktaları $950 \mathrm{~m}^{2}$ lik alanda kanyon bölgesine göre konumlandırılmıştır (Harita 8).

\section{Kavaklar Deresi Planlama Bölgesi Plan Kararları}

1/25000 ölçekli Ballıkayalar Tabiat Parkı Uzun Devreli Gelişim Planı'nda Kavaklar Deresi planlama bölgesi;

- Taşıt yolu ve otopark,

- Geleneksel ürün satış noktası,

- Günübirlik kullanım alanı,

- Çadırlı kamp alanı,

kullanım fonksiyonları belirlenmiştir (Harita 9). 


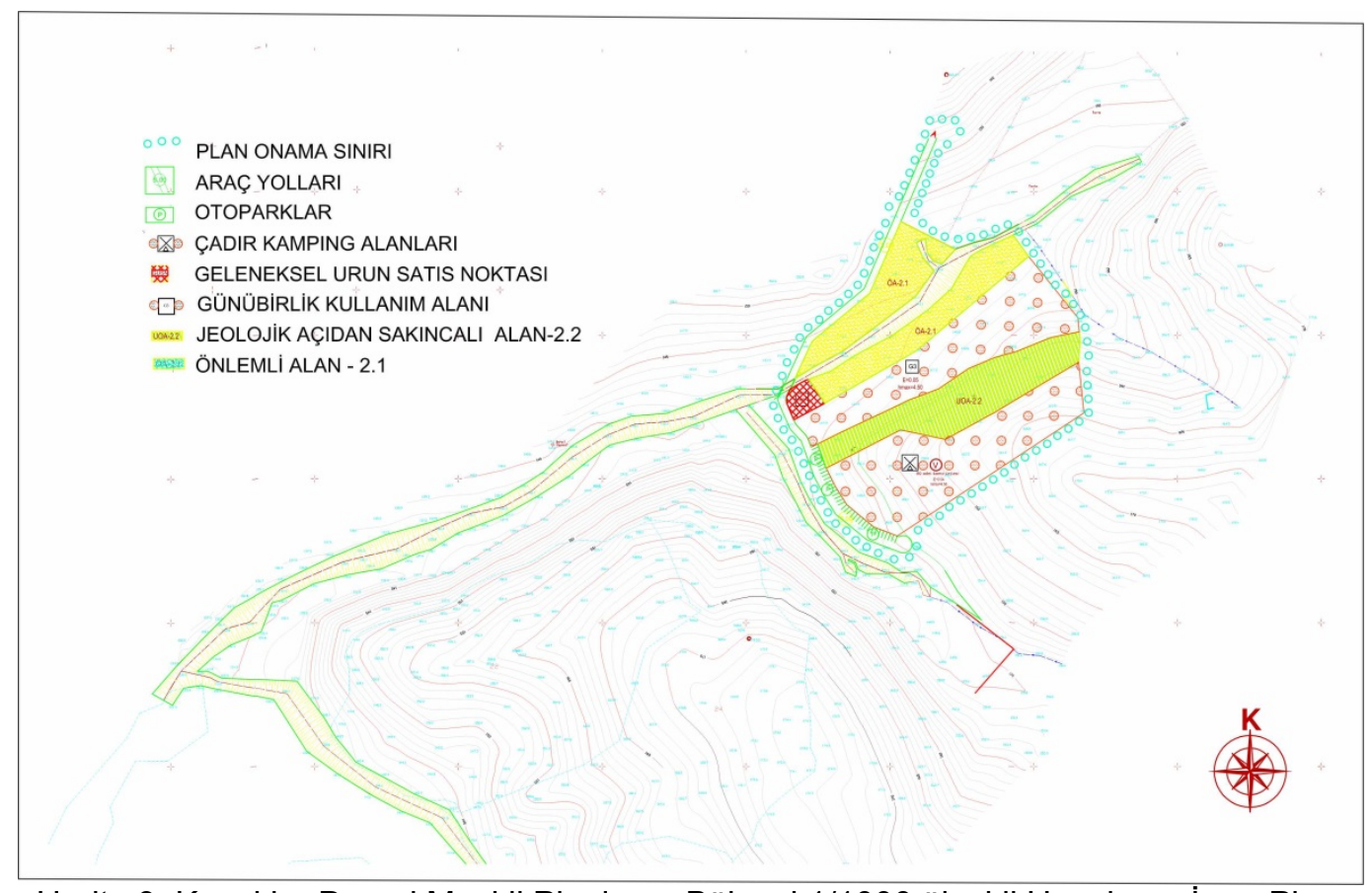

Harita 9: Kavaklar Deresi Mevkii Planlama Bölgesi 1/1000 ölçekli Uygulama İmar Planı

Kavaklar Deresi Bölgesi genelinde yaklaşık 36 araçlık otopark alanı oluşturulmuştur. Bölge bütününde $600 \mathrm{~m}^{2}$ 'lik alan üzerinde geleneksel ürün satış noktası (stant alanı) planlanmıştır. Kavaklar Deresi alanında, geleneksel ürün satış yapılarının stantlar şeklinde taşınabilir ve hmaks. (maksimum kat yüksekliği) olarak $4.50 \mathrm{~m}$. belirlenmiştir. $6 \mathrm{~m}^{2}$ 'yi geçmeyen büyüklükte birimler olarak düşünülmüştür.

Günübirlik kullanım alanı olarak $7000 \mathrm{~m}^{2}$ 'lik bir alan ayrılmıştır ve bu alan içerisinde alt kullanımlar (kır gazinosu, piknik alanı ve ortak kullanım alanları- spor tesisi, çocuk oyun alanı, otopark alanı, büfe, kır gazinosu ve tuvaletler-) bulunmaktadır. Günübirlik kullanım alanlarında maksimum yapılaşma alanı $319 \mathbf{m}^{2}$ (250 $\mathrm{m}^{2}$ 'lik kır gazinosu, $30 \mathrm{~m}^{2}$ lik tuvalet ve giyinme birimleri, $30 \mathrm{~m}^{2}$ 'lik ocak ve bulaşıkhane ve $9 \mathrm{~m}^{2}$ 'lik büfe) ve hmaks $4.50 \mathrm{~m}$. Olarak belirlenmiştir. $7000 \mathrm{~m}^{2}$ 'lik toplam günübirlik kullanım alanının $1400 \mathrm{~m}^{2}$ 'lik kısmı yol ve yeşil alanlar için, $5000 \mathbf{~ m}^{2}$ 'lik kısmı piknik alanı (5 kişilik bir aile için 1 piknik masası ve $200 \mathrm{~m}^{2}$ 'lik alan düşünüldüğünde toplam 25 ailelik), $250 \mathrm{~m}^{2}$ 'lik kır gazinosu, $150 \mathrm{~m}^{2}$ 'lik spor alanı, $50 \mathrm{~m}^{2}$ 'lik çocuk oyun alanı, $30 \mathrm{~m}^{2}$ 'lik tuvalet ve giyinme birimleri, $20 \mathrm{~m}^{2}$ 'lik ocak ve bulaşıkhane, $9 \mathrm{~m}^{2}$ 'lik büfe ve $10 \mathrm{~m}^{2}$ 'lik çöp toplama alanı olarak belirlenmiştir.

Kavaklar Deresi bölgesinde 4 adet ve her biri $2000 \mathrm{~m}^{2}$ olan çadırlı kamp alanları tasarlanmıştır. Çadırlı kamp alanları toplam $8000 \mathrm{~m}^{2}$ 'lik 80 çadırlık ve 240 kişilik tasarlanmıştır. Çadırlı kamp alanlarında, maksimum yapılaşma alanı $50 \mathbf{m}^{2}$ (tuvaletler ve duş alanları $30 \mathrm{~m}^{2}, 20 \mathrm{~m}^{2}$ çamaşırhane ve bulaşıkhane) ve hmaks (maksimum kat yüksekliği) olarak $4.50 \mathrm{~m}$. belirlenmiştir. $2000 \mathrm{~m}^{2}$ 'lik bir alan içinde $\mathbf{4 0 0} \mathrm{m}^{\mathbf{2}}$ 'lik kısmı yol, yeşil alan ve ortak kullanım alanları (tuvaletler ve duş alanları $30 \mathrm{~m}^{2}$, yakacak deposu $8 \mathrm{~m}^{2}$, bulaşıkhane 10 $\mathrm{m}^{2}$, çamaşırhane $10 \mathrm{~m}^{2}$, çöp toplanma alanı $5 \mathrm{~m}^{2}$, su deposu $5 \mathrm{~m}^{2}$, ocak ve yeme pişirme alanı $12 \mathrm{~m}^{2}$ ), $1600 \mathrm{~m}^{2}$ 'lik alan ise kamp üniteleri (60 kişilk 20 kamp ünitesi) için düşünülmüştür.

Ballıklayalar Tabiat Parkı dört plan bölgesinde yapılan 1/1000 ölçekli koruma amaçlı uygulama imar planı planlama kararları Tablo 3 de özetlenmektedir: 
Türkiye'de Tabiat Parkları Koruma Amaçlı İmar Planlama Süreci: Ballıkayalar Tabiat Parkı Deneyimi Conservation Oriented Development Planning Process in Turkey: Ballıkayalar Natural Park Experience

Tablo 3. Ballıkayalar Tabiat Parkı Koruma Amaçlı İmar Planı Planlama Bölgeleri Plan Kararları

\begin{tabular}{|c|c|c|c|}
\hline $\begin{array}{l}\text { Ballıkayalar Kanyonu ve } \\
159 \text { Rakımlı Tepe }\end{array}$ & Kocamezarlık & Değirmendere & Kavaklar Deresi \\
\hline $\begin{array}{l}\text { Taşıt yolu ve otopark } \\
\text {-Kanyon bölgesi } 18 \text { araçlık } \\
\text {-Tepe bölgesi } 82 \text { araçlık }\end{array}$ & $\begin{array}{l}\text { Taşıt yolu ve otopark } \\
-30 \text { araçlık }\end{array}$ & $\begin{array}{l}\text { Taşıt yolu ve otopark } \\
-35 \text { araçlık }\end{array}$ & $\begin{array}{l}\text { Taşıt yolu ve otopark } \\
-36 \text { araçlık }\end{array}$ \\
\hline $\begin{array}{l}\text { Giriş kontrol noktası } \\
-140 \mathrm{~m}^{2} \text { alanda maks } 6 \mathrm{~m}^{2}\end{array}$ & $\begin{array}{l}\text { Manzara seyir noktası } \\
1255 \mathrm{~m}^{2} \\
\text {-ahşap platformlar } \\
\text {-korkuluklar } \\
\text {-yönlendirici birimler } \\
\text {-tanıtıcı panolar } \\
\end{array}$ & $\begin{array}{l}\text { Gezici kontrol birimi } \\
-185 \mathrm{~m}^{2} \text { alanda } 6 \mathrm{~m}^{2}\end{array}$ & $\begin{array}{l}\text { Geleneksel ürün satış } \\
\text { noktası } 600 \mathrm{~m}^{2} \\
\text {-Her biri } 6 \mathrm{~m}^{2} \text { olmak üzere } \\
\text { maks } 10 \text { adet stant birim }\end{array}$ \\
\hline $\begin{array}{l}\text { İdare, ziyaretçi ve tanıtım } \\
\text { merkezi } \\
\quad-500 \mathrm{~m}^{2} \text { alanda } 250 \mathrm{~m}^{2}\end{array}$ & & $\begin{array}{l}\text { Manzara seyir noktası } \\
950 \text { m }^{2} \\
\text {-ahşap platformlar } \\
\text {-korkuluklar } \\
\text {-yönlendirici birimler } \\
\text {-tanıtıcı panolar }\end{array}$ & $\begin{array}{l}\text { Günübirlik kullanım alanı } \\
7000 \mathrm{~m}^{2} \\
\text {-Kır gazinosu } 250 \mathrm{~m}^{2} \\
\text {-Hizmet alanları } 70 \mathrm{~m}^{2} \\
\text {-Büfe } 9 \mathrm{~m}^{2} \\
\text {-Piknik Alanı } 5000 \mathrm{~m}^{2} \\
\text {-Yol ve yeşil alanlar } 1400 \\
\mathrm{~m}^{2} \\
\text {-Açık spor alanı } 150 \mathrm{~m}^{2} \\
\mathrm{~m}^{2}\end{array}$ \\
\hline $\begin{array}{l}\text { Geleneksel ürün satış } \\
\text { noktası(Kanyon ve Tepe } \\
\text { Bölgesinde } 2 \text { alanda } 250 \mathrm{~m}^{2} \\
+1550 \mathrm{~m}^{2} \\
\text {-Kanyon bölgesinde, her biri } \\
6 \mathrm{~m}^{2} \text { olmak üzere maks } 4 \text { adet } \\
\text { stant birim } \\
\text {-Tepe bölgesinde, her biri } \\
6 \mathrm{~m}^{2} \text { olmak üzere maks } 25 \text { adet } \\
\text { stant birim }\end{array}$ & & & $\begin{array}{l}\text { Çadırlı kamp alanı } 8000 \mathrm{~m}^{2} \\
\text {-her biri } 2000 \mathrm{~m}^{2} 4 \text { adet } \\
\text { toplam } 80 \text { çadırlık } 240 \text { kişilik } \\
\text { çadır alanı } \\
\text { Her bir kamp alanında; } \\
\text {-Yol, yeşil ve ortak } \\
\text { kullanım alanları } 400 \mathrm{~m}^{2} \\
-60 \mathrm{kişilik} 20 \text { kampçı ünitesi }_{1600 \mathrm{~m}^{2}}\end{array}$ \\
\hline \multicolumn{4}{|l|}{$\begin{array}{l}\text { Günübirlik kullanım alanı } \\
7000 \mathrm{~m}^{2} \\
\text {-Kır gazinosu her biri } 250 \mathrm{~m}^{2} \\
\text { olmak üzere } 2 \text { adet } \\
\text {-Hizmet alanları } 70 \mathrm{~m}^{2} \\
\text {-Büfe } 9 \mathrm{~m}^{2} \\
\text {-Piknik Alanı } 5000 \mathrm{~m}^{2} \\
\text {-Yol ve yeşil alanlar } 1400 \mathrm{~m}^{2} \\
\text {-Açık spor alanı } 150 \mathrm{~m}^{2} \\
\text {-Açık çocuk oyun alanı } 50 \\
\mathrm{~m}^{2}\end{array}$} \\
\hline \multicolumn{4}{|l|}{$\begin{array}{l}\text { Çadırlı kamp alanı } 20000 \mathrm{~m}^{2} \\
\text {-Kanyon bölgesinde her biri } \\
2000 \mathrm{~m}^{2} 4 \text { adet toplam } 80 \\
\text { çadırık } 240 \text { kişilik çadır alanı } \\
- \text { Tepe bölgesinde her biri } \\
2000 \mathrm{~m}^{2} 6 \text { adet toplam } 120 \\
\text { çadırık } 360 \text { kişilik çadır alanı } \\
\text { Her bir kamp alanında; } \\
\text {-Yol, yeşil ve ortak kullanım } \\
\text { alanları } 400 \mathrm{~m}^{2} \\
-60 \mathrm{kişilik} 20 \text { kampçı ünitesi }_{1600 \mathrm{~m}^{2}}\end{array}$} \\
\hline $\begin{array}{l}\text { Manzara seyir noktası } 420 \\
\mathrm{~m}^{2} \\
\text {-ahşap platformlar } \\
\text {-korkuluklar } \\
\text {-yönlendirici birimler } \\
\text {-tanıtıcı panoları }\end{array}$ & & & \\
\hline
\end{tabular}




\section{DEĞERLENDIRME VE SONUÇ}

"Korunan Alanlar" kapsamına giren tabiat parkları; doğal, coğrafi yapı, flora ve fauna özelliklerine sahip, dikkat çekici, rekreatif faaliyetler yapılabilen, çeşitli mevzuat hükümlerine göre belirlenerek koruma altına alınan alanlar olarak tarif edilmektedir. Günümüzde bu alanlar insan faaliyetleri baskısı ile kaynak değerlerini kaybetme tehdidi altındadır. Bu kaynakları korumak, sürekliliğini sağlamak ve geliştirmek için Tabiat Parklarında koruma-kullanma dengesi içinde tesis edilen kullanım alanlarında, doğa ile uyumlu yaşama olanağı bulunmakta ve doğal ortamın kaynak ve peyzaj değerlerini tanıma fırsatı elde etmek mümkündür. Bu amaçla Dünya'da ve Türkiye'de planlama çalışmaları yapılmaktadır. Yaklaşımlar temelde aynı olmakla birlikte planlama sürecinde farklılıklar ortaya çıkmaktadır. Türkiye'de 223 adet tabiat parkının 101 adedinin üst ölçek Uzun Devreli Gelişme Planı olması yanında, kullanım alanlarına ilişkin alt ölçek imar planlarının yeterince oluşmadığı görülmektedir.

Bu kapsamda, üniversite-kamu kuruluşu işbirliği çerçevesinde gerçekleşen, 2005 yılında Çevre ve Orman Bakanlığı, Doğa Koruma ve Milli Parklar Genel Müdürlüğü (günümüzde T.C. Orman ve Su işleri Bakanlığı Doğa Koruma ve Milli Parklar Genel Müdürlüğü) tarafından yaptırılan "Ballıkayalar Tabiat Parkı 1/25000 Ölçekli Uzun Devreli Gelişme Planı"nının genel planlama kararlarına göre hazırlanan "Balıkayalar Tabiat Parkı Koruma Amaçlı İmar Planı" çalışmasında "planlama hiyerarşisi" ve "planlar arası kademeli birliktelik" yaklaşımları doğrultusunda uzun devreli gelişim planının genel ve mutlak koruma alanı, sınırlı kullanım alanı, kontrollü kullanım alanı olarak tanımlanan 3 bölge için plan kararlarına uyumlu olacak şekilde kullanım kararları öngörülmüş, kamusal açık alan, koruma- kullanma dengesi, rekreatif kullanımlar kavramlarını merkeze alan çalışma bütününde genel planlama kararları, uluslararası tabiat parklarında yapılan iyi uygulamalar da baz alınarak oluşturulan uygulamaya dair plan kararları, imar planları, plan lejantları, plan notlarına işlenerek analiz- plan- program- uygulama etapları bütününde bir süreç tarifi yapılmıştır. Bu çalışmanın, ulusal ölçekte tabiat parkı imar planlama çalışmalarına katkı sunması beklenmektedir. 
Türkiye'de Tabiat Parkları Koruma Amaçlı İmar Planlama Süreci: Ballıkayalar Tabiat Parkı Deneyimi

Conservation Oriented Development Planning Process in Turkey: Ballıkayalar Natural Park Experience

\section{KAYNAKLAR}

Doğanay, Hayati, Türkiye Turizm Coğrafyası, 3.Basım, Çizgi Kitapevi Yayınları, Konya, 2001.

Lowry, William R., "Providing Intergenerational Goods: Implementation of National Park System Plans in Canada and the United States", Policy Studies Journal, Vol. 27, No. 2, 1999 s:328-346.

Palut, Doğan \& Aydıngün, Haldun, Balıkayalar, Homer Kitapevi ve Yayıncılık, İstanbul, 2002.

Province of British Colombia, Ministry of Environment Lands and Park, Park Design Guidelines and Data, $2^{\text {nd }}$ ed., British Colombia, 1998.

Resmi Gazete, 2873 sayılı Milli Parklar Kanunu, Sayı: 18132, 1983a.

Resmi Gazete, 2863 sayılı Kültür ve Tabiat Varlıklarını Koruma Kanunu, Sayı: 18113, 1983b.

Resmi Gazete, 3194 sayılı İmar Kanunu, Sayı: 18749, 1985.

Resmi Gazete, Milli Parklar Yönetmeliği, Sayı: 19309, 1986.

Resmi Gazete, Milli Parklar Yönetmeliğinde Değişiklik Yapılmasına Dair Yönetmelik, Sayı: 28945, 2014a.

Resmi Gazete, Koruma Amaçlı İmar Planları ve Çevre Düzenleme Projelerinin Hazırlanması, Gösterimi, Uygulaması, Denetimi ve Müelliflerine İlişkin Usul ve Esaslara Ait Yönetmelik, Sayı: 25887, 2005.

Resmi Gazete, Korunan Alanlarda Yapılacak Planlara Dair Yönetmelik, Sayı: 28242, 2012.

Resmi Gazete, Mekansal Planlar Yapım Yönetmeliği, Sayı: 29030, 2014b.

Resmi Gazete, Koruma Amaçlı İmar Planları ve Çevre Düzenleme Projelerinin Hazırlanması, Gösterimi, Uygulaması, Denetimi, Müelliflerine İlişkin Usul ve Esaslara Ait Yönetmelikte Değişiklik Yapılmasına Dair Yönetmelik, Sayı: 29939, 2017a.

Resmi Gazete, Doğal Sit Alanları Koruma ve Kullanma Koşulları İlke Kararı, Sayı: 29959, 2017b.

Stockdalea, Aileen \& Barker, Adam, "Sustainability and the multifunctional landscape: An assessment of approaches to planning and management in the Cairngorms National Park", Land Use Policy, 26, 2009, 479-492.

T.C. Çevre ve Orman Bakanlığı Doğa Koruma ve Milli Parklar Genel Müdürlüğü, Ballıkayalar Tabiat Parkı 1/25000 Ölçekli Uzun Devreli Gelişme Planı Çalışması - Analitik Etüt ve Sentez/Değerlendirme Raporu, Çevre ve Orman Bakanlığı Yayınları, Ankara, 2004.

T.C. Çevre ve Şehircilik Bakanlığı, 2014/23 nolu Korunan Alanlarda Yapılacak İmar Planı Teklifi Usul ve Esaslarına İlişkin Genelge, 2014. 
T.C. Orman Bakanlığı Milli Parklar ve Av-Yaban Hayatı Genel Müdürlüğü, Ballıkayalar Vadisi Kataloğu, Berkay Ofset, İstanbul, 2003.

Türkiye Çevre Koruma ve Yeşillendirme Kurumu, Ballıkayalar Vadisi Tabiat Parkı Envanter Raporu, Ankara, 1994.

U.S. Department of the Interior, National Park Service, Guiding Principles of Sustainable Design, Denver Service Center, 1993.

Zhou, D.Q. \& Grumbine, R. Edward, "National parks in China: Experiments with protecting nature and human livelihoods in Yunnan province, Peoples' Republic of China (PRC)",

Biological Conservation, 144, 2011, 1314-1321.

URL-1:

http://www.iucn.org/about/work/programmes/gpap_home/gpap_quality/gpap_pacategories/, Erişim Tarihi: 27.01.2013.

URL-2:

http://www.bfn.de/fileadmin/MDB/documents/themen/gebietsschutz/Tabelle_Naturparke_07_12. pdf, Erişim Tarihi: 27.01.2013.

URL-3:

http://www.bfn.de/fileadmin/MDB/documents/themen/gebietsschutz/Naturparkkarte_Juli_2012.p df, Erişim Tarihi 27.01.2013.

URL-4: http://www.naturparke.at/en/VNOe/What_is_a_Nature_Park, Erişim Tarihi: 28.01.2013.

URL-5: http://www.naturparke.at/en/VNOe/Map_Overview, Erişim Tarihi: 28.01.2013.

URL-6: http://www.parcs-naturels-regionaux.tm.fr/fr/approfondir/federation.asp, Erişim Tarihi: 28.01.2013.

URL-7: http://www.parcs-naturels-regionaux.fr/fr/approfondir/qu-est-ce-qu-un-parc.asp, Erişim Tarihi: 28.01.2013.

URL-8:http://www.parcs-naturelsregionaux.tm.fr/upload/doc_telechargement/grandes/Carte\%20Postale_Parcs.pdf, Erişim Tarihi: 28.01.2013.

URL-9: https://www.pc.gc.ca/en/pn-np/introduction, Erişim Tarihi: 13.03.2018.

URL-10: https://www.pc.gc.ca/en/pn-np/plan, Erişim Tarihi: 13.03.2018.

URL-11: http://www.tabiat.gov.tr/tr/searchplaces, Erişim Tarihi: 27.01.2018

URL-12: http://www.milliparklar.gov.tr/korunan-alanlar/tp4, Erişim Tarihi: 16.03.2018.. 